\title{
COMMUNITY ENGAGEMENT IN FOREST REHABILITATION WITHIN THE CONTEXT OF A TROPICAL ISLAND: INSIGHTS FROM PRASLIN, SEYCHELLES
}

\author{
Etongo, D..$^{1,2^{*}}$ - BARBe, R. $.^{2,3}-$ Monthy, M. ${ }^{3}$ - Millett, J. ${ }^{3}$ - HenRiette, E. ${ }^{4,5}-$ Vel, T. ${ }^{2}$ \\ ${ }^{1}$ James Michel Blue Economy Research Institute, P.O. Box 1348, Anse Royale, Mahé, \\ Seychelles
}

${ }^{2}$ Department of Environmental Sciences, P.O. Box 1348, Anse Royale, Mahé, Seychelles

${ }^{3}$ GOS-UNDP-GEF Programme Coordination Unit, Victoria, Mahé, Seychelles

${ }^{4}$ Island Biodiversity and Conservation Centre, P.O. Box 1348, Anse Royale, Mahé, Seychelles

${ }^{5}$ Terrestrial Restoration Action Society of Seychelles, P.O. Box 4057, Baie Ste. Anne, Praslin, Seychelles

*Corresponding author
e-mail: Daniel.Etongo@unisey.ac.sc; phone: $+248-438-1222$

(Received $5^{\text {th }}$ Jun 2021; accepted $3^{\text {rd }}$ Sep 2021)

\begin{abstract}
Community involvement gained momentum after the establishment of the Terrestrial Restoration Action Society Seychelles (TRASS) in 2009 to address the concerns of forest rehabilitation on the fire ravaged lands on Praslin. This study assesses issues pertaining to community participation in forest rehabilitation and proposes strategies for improvement. Three shared-dialogue workshops and 180 household surveys conducted via a stratified random sampling was applied for the data collection. The collected data was analyzed using the Statistical Package for Social Sciences (SPSS) version 20. Results indicated that arson, accidents during agricultural practices, negligence during rubbish burning, cigarettes butts on trails and harvesting wild honey as well as the extended drought period during the dry season are the predominant causes of forest fires on Praslin. Membership in a community-based organization was the only determinant that influenced household participation in forest rehabilitation while other factors such as household size, age, gender and number of schooling years were not significant. Most benefits of forest rehabilitation were perceived in-kind rather than financial through the provisioning of ecosystem goods and services. Technical challenges manifesting in the form of inadequate knowledge and skills for tree planting on very steep slopes often covered with boulders and also exposed to soil erosion were of greater concern. This reinforces the point that forest rehabilitation needs to be adaptive to local conditions in order for it to prevail and it is a learning-by-doing process to develop the best practices that can ensure greater success. Lastly, some proposed strategies for improvement of rehabilitation programmes include awareness and education campaigns, additional manpower, the development of an efficient monitoring and evaluation system, conducting regular enrichment planting, and also greater involvement of community members at the planning stage but also during the execution of forest rehabilitation programmes.
\end{abstract}

Keywords: forest landscape, participation, capacity building, tree knowledge, forest fire, TRASS

\section{Introduction}

Forest degradation goes beyond a reduction of the forest area to a decrease in the quality of forest which in turn affects the ecosystem goods and services they provide (Yin et al., 2016). Despite the importance of forests as a source of income, food values, protection of watersheds, carbon and sinks among others, the conversion of grasslands, woodlands, and forests into croplands and pastures has risen dramatically 
during the last two decades globally. For example, disturbances in tropical dry forests have resulted in the fragmentation, degradation, and in some cases disappearance of these forests (Mbow et al., 2013). The main drivers behind these changes are a combination of population growth (Stéphenne and Lambin, 2004), rising demand for agricultural products, dietary changes, agricultural trade and adjustment, dependence on wood energy, recurrent bush fires (Ouedraogo et al., 2015), infrastructural development (mainly road construction), expansion of settlements and agricultural fields (Makunga and Misana, 2017).

Madagascar, one of the 34 global biodiversity hotspots has a high prevalence for forest degradation. According to Yesuf et al. (2019), such degradation is mainly driven by weak governance structure and unclear land tenure that has necessitated the encroachment of large-scale commercial agriculture into forest areas. Furthermore, Sudan is considered a hotspot for forest degradation with dramatic land use change from $5.3 \%$ in 1973 to $22.2 \%$ in 2016 in the Erawashda forest driven by an increase in cultivated land through mechanized farming into forest areas (Sulieman, 2018). Corroborating the views of other studies, Vásquez-Grandón et al. (2018) concluded that over exploitation of forests products is the primary drivers of forest degradation, alongside overgrazing, wildfires, and the spread of invasive species or pests. Between the years 2001 to 2015, 27\% of global forest loss was caused by permanent land use change for commodity production and 23\% due to wild fire (Curtis et al., 2018).

In the case of Seychelles, deforestation and forest degradation (DD) can be traced to two main phases of historic forest loss - commercial logging of timber between 1770c1820 and then between c1910-1970s for cinnamon extraction and distillation (Kueffer et al., 2013). Therefore, historical events such as unsustainable harvesting of timber and forest products also played a major role in removing vegetation and thereby exacerbating the impacts of climate change on the exposed top soil layer. After the first settlement of humans some 240 years ago there was widespread exploitation of hard wood from the forest for various uses including housing and boat construction in Seychelles (Etongo et al., 2019). In addition, DD is severe given the total landmass of $455 \mathrm{~km}^{2}$ (GoS, 2020) spread across 115 islands, with intense land use competition from multiple uses as a consequence. More than $80 \%$ of the land area on Praslin and Curieuse Island has been affected by forest fires and consequent severe erosion. Dry weather conditions due to the extended period of drought during the dry season (Fleischmann et al., 2020) coupled with the availability of flammable materials in the forest create ideal conditions for forest fires to occur (Senterre, 2009). The exposed top soil with its little organic matter on the predominantly mountainous landscape in Seychelles (see Fig. 1) are easily eroded by runoff after torrential rainfall.

Although the causes of forest fires are human-induced, climate change manifestation through the extended period of drought during the dry season have created a favorable condition for fire to occur, persist and spread in the forest. Therefore, the predominant causes of fire on Praslin are anthropogenic but amplified by the impacts of climate change - a view supported by Senterre (2009). According to this same study, the main drivers of forest fires in the Seychelles are human ignition (proximity to trails), vegetation (post-fire colonizing species are more fire prone) and environment (dry spell, and topography). The amount of fuel available in the understory, e.g. typically palm forests with a relatively larger amount of fuel on the ground from the palm leaves are more vulnerable to fire outbreak. The climate change projections in Seychelles shows that rainfall, while increasing in overall terms, will become even more irregular (GoS, 
2020). Much of the precipitation is falling in sharp bursts, creating heavy flooding in the wet season, while imposing an extended period of drought during the dry season (Fleischmann et al., 2020).

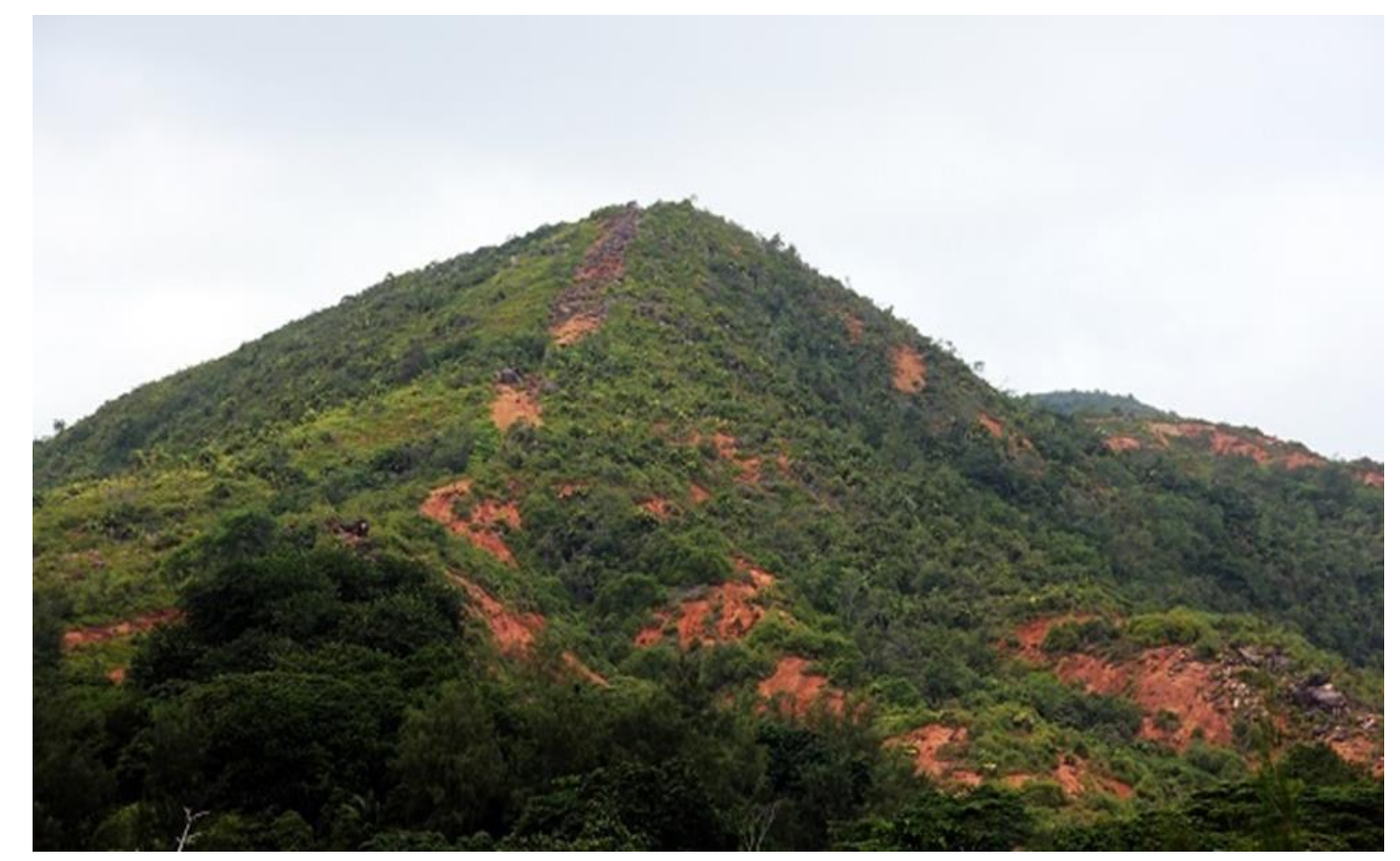

Figure 1. La Hauteur Mountain, overlooking the district of Baie Ste Anne, has been sporting bare red patches for almost thirty years following forest fires and soil erosion. Photo credit:

Romano Laurence (Seychelles News Agency, 2015)

Historically fires were set on purpose on both Praslin and Curieuse by the sailors/traders as a result of disputes. They collected the priceless Coco-de-mer nut and then set fires so that others could not get access to them but also to force the prices of the Coco-der-mer up on the international market. This was before the 1700. After colonization of the Seychelles in 1772 and much later on in the 1900, fires were mainly accidental during agricultural practices. Battles between pirates, around 1700, conflicts between groups of settlers around 1770, then war between French and English around 1800 , etc., have resulted in unprecedented forest fires especially on the grounds of the Coco-de-mer, whereby fires were set on the Coco-de-mer forests to raise its value on the market (Senterre, 2009). The development of agriculture and timber extraction in the $19^{\text {th }}$ century, and the development of the cinnamon industry, in the $20^{\text {th }}$ century, have further deforested lands, increasing their flammability. During the heated political times of the 1960 s to 1980 s fires were set deliberately due to political frustrations but also because of conflicts between neighbours (arson fires as a protest tool). Forest fires during this period on average occurred twice a year and it destruction on the vegetation cover was relatively extensive, burning up to 20 ha which has diminished to 1-2 ha with some years without fire outbreak in the forest (Senterre, 2009). The other main cause of forest fire is negligence while burning rubbish, cigarette stump thrown on trails or harvesting wild honey, and also results from the non-awareness of importance of forests for the community (Senterre, 2009). Forest fires have become recurrent during the last 
five decades with vast expanse of both private and public lands including the National Park on Praslin being ravaged by fires. This lead to the initial forest rehabilitation activities on Praslin and elsewhere in Seychelles pioneered by the government entities responsible for forestry and National Parks. However, community engagement was minimal given that rehabilitation activities were mostly implemented by contractors and government staffs in the environment and forestry divisions. The creation of a nongovernmental organization - the Terrestrial Restoration Society of Seychelles (TRASS) in 2009 became a game changer and has witnessed community participation through volunteerism on the one hand (Seychelles News Agency, 2015), and on the other hand, building partnership through joint implementation of projects with government institutions such as the Ministry of Agriculture, Climate Change and Environment (MACCE) and Seychelles National Parks Authority (SNPA).

For example, during a one-day activity organized by TRASS in November 2020, a total of 1,000 seedlings of native tree species were planted at Pasquière, Praslin Island by a group of volunteers from Raffles Hotel, Seychelles Employee Transition Scheme (SETS), Seychelles Island Foundation (SIF), as well as students from Vijay International, Baie Ste. Anne and Grand Anse schools (Seychelles News Agency, 2020). Involving local community in forest rehabilitation activities from the planning, design, implementation and monitoring of such interventions has the potential for greater success and concomitantly to ensure sustainability when rehabilitation projects phase out. Community engagement in forest rehabilitation has multiple benefits including social learning through peer to peer support, development and transfer of new skills, increase awareness on the importance of forest in terms of livelihood values and environmental protection.

One of the main objectives of TRASS is to rehabilitate fire ravaged forests on Praslin and in order to achieve this objective, an estimated 15,000 endemic plants are cultured every year for this purpose at the TRASS nursery. Tree and mangrove planting activities are carried out on a voluntary basis witnessing the participation of community members of different age groups and even tourists in some cases. Continuous engagement with schools and local communities is an effective way to pass on relevant information and raise awareness on sensitive issues regarding management of forests (Senterre, 2015). Forest rehabilitation is a process and not an activity that could be limited solely to tree planting. It also contributes to Sustainable Development Goals 13 and 15 - Climate Action, and Life on Land. More importantly, forest rehabilitation is not limited to Praslin but occurring on other islands in the Seychelles. The total land area rehabilitated by TRASS is 23 ha during phase 1 and 2 of the Ecosystem Based Adaptation (EBA) project where 5 ha (2016-2017) and 18 ha (2019-2020) respectively. The phase 1 was mostly a learning-by-doing process in which the seedlings of native trees were planted on predominantly mountainous landscapes with steep slopes that have very little humus layer, from which lessons were learnt to ensure that best practices were implemented in phase 2. Therefore, insights from community involvement in forest rehabilitation and some lessons learnt especially within the context of a Small Island Developing State (SIDS) can provide baseline information to guide future rehabilitation projects on Praslin and elsewhere in the Seychelles. This study therefore addresses the following issues: (i) causes of forest fires on Praslin based on community perceptions, (ii) determinants and levels of household participation in forest rehabilitation, (iii) challenges and benefits of forest rehabilitation, and (iv) proposed strategies to improve forest rehabilitation. 


\section{Forest rehabilitation - conceptual perspective}

\section{Motivational drivers and types of participation in forest rehabilitation}

Rehabilitation is often used interchangeably with ecological restoration with the most recent and comprehensive definition provide by the Society for Ecological Restoration (SEC) (Gann et al., 2019). Rehabilitation: Management actions that aim to reinstate a level of ecosystem functioning on degraded sites, where the goal is renewed and ongoing provision of ecosystem services rather than the biodiversity and integrity of a designated native reference ecosystem. Ecological restoration: The process of assisting the recovery of an ecosystem that has been degraded, damaged, or destroyed. (Ecosystem restoration is sometimes used interchangeably with ecological restoration, but ecological restoration always addresses biodiversity conservation and ecological integrity, whereas some approaches to ecosystem restoration may focus solely on the delivery of ecosystem services). While the latter is to restore a degraded forest to its original state - that is, to re-establish the presumed structure, productivity and species diversity of the forest originally present at a site, the former which is the focus of the current study, is to restore the capacity of degraded forest land to deliver forest products and services. The philosophy of participation is no longer new to forest rehabilitation (Evans et al., 2017). Viewed as a catalyst of social change, participation has not only been spread through technology transfer in development research, but also by challenging state control in the management of natural resources (Ballet et al., 2009). Participation involves three interconnected, but different processes: (i) the involvement of local communities in decision-making; (ii) the inclusion of local community's perspectives into programmes; and (iii) the assurance of community participation in benefit sharing from the process (United Nations, 1975).

The application of participatory methodologies in natural resource governance has been acknowledged by development practitioners as an effective mechanism for managing existing conflicts, while minimizing the tendency for future conflicts to occur (FAO, 2014). Despite this acknowledgment, participation has been described in some cases as a new form of tyranny (Cooke and Kothari, 2001), especially in cases where tokenism predominates, shielding the dominance of elites who end up capturing the entire forest rehabilitation process and the benefits thereof (Arnstein, 1969). In this regard, those who participate in the management of natural resources in general and forest rehabilitation in particular are hardly the true representatives of stakeholders who are directly affected by the decisions being made (Marshall and Jone, 2005). Agarwal's typology (Agarwal, 2001) presents a useful tool to appreciate different forms of participation in which he identified six levels of participatory behavior (Table 1). In principle, people's perceived benefits could improve their participation, placing them within the active and interactive participation strata. However, several factors (beyond perceived benefits) could also shape people's decision to participate in these arrangements.

Some of the scientific literatures have proven that the driving force behind participation in forest rehabilitation is contextual as people are motivated to participate due to their embedded socio-cultural, economic, and political benefits (Bagdi and Kurothe, 2014). Some of the widely documented drivers include cultural benefits, financial benefits, incentives, and prior established links with conservation agencies, among others (Raufirad et al., 2017). The literature on what motivates people to participate in forest rehabilitation is negligible, at least in the context of 
Seychelles. This study contributes to unmask the range of factors that (de)motivate community members' participation in forest rehabilitation in the context of Seychelles and Praslin Island in particular. Lessons learnt from ongoing rehabilitation activities are essential to inform future forest rehabilitation in the Seychelles given the increase in degraded forest areas amidst recurrent forest fires under the impacts of a changing climate.

Table 1. Agarwal's typology of participation

\begin{tabular}{c|c}
\hline Form of participation & Characteristic features \\
\hline Nominal participation & Membership in the group \\
\hline Passive participation & $\begin{array}{c}\text { Being informed of decisions ex post facto; or attending } \\
\text { meetings and listening decision-making, without speaking up }\end{array}$ \\
\hline Consultative participation & $\begin{array}{c}\text { Being asked an opinion in specific matters without guarantee } \\
\text { of influencing decisions }\end{array}$ \\
\hline Activity-specific participation & Being asked to (or volunteering to) undertake specific tasks \\
\hline Active participation & $\begin{array}{c}\text { Expressing opinions, whether solicited, or taking initiatives of } \\
\text { other sorts }\end{array}$ \\
\hline Interactive (empowering) participation & Having voice and influence in the group decision-making \\
\hline Source: Adopted from Agarwal (2001) &
\end{tabular}

\section{Guidelines for forest rehabilitation}

Brown and Lugo (1994) characterized rehabilitation as a management strategy to reverse the negative impacts of deforestation and degradation. Achieving such an objective that has potential for environmental win-win will require adhering to certain guidelines that has proven to deliver a greater rate of success. Elliott et al. (2013) also suggested five actions that are important for forest rehabilitation as follows: (i) removing stressors such as forests fires, over grazing and biomass loss, (ii) to add animals and plants to the area depending on the level of degradation, (iii) experimental work by Schumacher indicated that additional nutrient conferred few benefits to endemic species and great benefits to non-native species - obviously this is a very different situation on fire degraded lands on Praslin that have lost humus compared to Mahe. Trials on Praslin indicated that adding humus and charcoal to plant increased plant growth by 2- 4 times. The addition of calcium carbonate through coral fill to improve soil $\mathrm{pH}$ also had beneficial advantages (Henriette et al., 2013; Senterre et al., 2012), (iv) regulating energy inputs in the system as a means of controlling ecosystem development, and (v) removing the most high impact stressors (e.g. poor land policy and overharvesting/exploitation of forest resources). The latter two is said to be the most difficult and time consuming (Brown and Lugo, 1994). Budiharta et al. (2014) stresses on the importance of identifying the characteristics of the degraded sites and level of degradation before choosing the rehabilitation techniques. For example, highly degraded forest lands may require intensive tree planting with a high cost compared to minimally degradation forest lands in which low-cost options such as enrichment planting (gap or strip planting) might be imperative. Additionally, the biodiversity of the area is an important consideration given that Key Biodiversity Areas (KBA) are hotspots that should be prioritized for rehabilitation/buffer zones so as to restore ecosystem goods and services. 
In order to ensure greater success rate in forest rehabilitation, Hahn et al. (2004) put forward the following guidelines as follows: (i) reduce the use of clear cutting, instead make use of productive and stable tree species, which secure soil fertility, (ii) use local variation and natural succession to secure constant supply of species and promote rare, native species, (iii) only native species should be used, except in circumstances where exotic species fulfill requirements such as site adaptation and biological integration, (iv) use species whose growth are not dependent on pesticides and or fertilizers, (v) promote and use natural regeneration techniques, (vi) apply an ecosystem based technique that will have minimal impact on the environment and on the local communities, (vii) securing biodiversity by creating forest reserves and promoting silviculture, and (viii) getting local community involved in the process and enhance their interactions with the forest through increasing aesthetic values and recreational opportunities and potential for economic activities is also an encouragement for participation.

Some considerations pertaining to forest rehabilitation in the case of Seychelles include climatic condition, nature of the topography, soil quality and vegetation types which have an impact on site selection and costs for rehabilitation. More importantly, the choice of site for rehabilitation is dependent on a number of factors such as its land use, proximity to high biodiversity areas, the human and financial resources available, and land ownership. According to Senterre et al. (2012), the predominant rehabilitation technique on degraded forest lands on Praslin is through strip clearing (only done in shrublands dominated by Chrysobalanus-Dicrapnopteris thickets) and tree planting mainly with native tree species while exotic species are used only in trials to compare with native species. The ecology of plant species should also be considered to achieve better success. Initial forest rehabilitation trials were conducted by TRASS from 2010 to 2014 with the aim of implementing the guidelines that reflects local realities. Despite some recorded success stories, ensuring the sustainability of forest rehabilitation activities should consider the availability of tree seedlings in nurseries, knowledge on planting techniques and preferred season for planting, nutrient supply for newly planted trees, continuous implementation of enrichment planting, proper maintenance of fire breaks, constant removal of invasive plant species and the active participation of community members at the planning, implementation and monitoring stages of forest rehabilitation.

\section{Community-based forest rehabilitation in Seychelles}

Involving local community in forest rehabilitation activities from the planning, implementation and monitoring are important to ensure sustainability of rehabilitation activities because skills and capacity are built across different levels. Community participation in forest rehabilitation is not new in the Seychelles. It can be traced to several projects and activities implemented during the last four decades by the Plant Conservation Action (PCA) group of Seychelles, SNPA and the MACCE (Kapisen, 2008). The momentum was rekindled by TRASS - a local NGO that has been in existence for 12 years with the mandate to restore the degraded forest areas on Praslin through the active engagement of local communities. Its effort has been to rehabilitate fire ravaged forest areas under private and public ownership.

A large area of the Praslin National Park is also being rehabilitated by TRASS. With support from mostly volunteers from both the public and private sector, TRASS has been able to achieve its target on planting trees and mangroves. For example, between 2015 to 2019, a total of 24,923 trees were planted on Praslin with the assistance of 
1,166 volunteers excluding TRASS own members. Most of the plantings occurred during the North West Monsoon between October to March, during which Seychelles experiences the most rainfall - an ideal situation for the growth of plants. The community engagement approach targets all individuals from Praslin and other nearby islands (Senterre et al., 2012). Community based rehabilitation has proven to be quite effective and is gaining more popularity as an effective approach to ensure sustainability of forest management while also promoting benefits for local livelihoods and the environment (Blay et al., 2008).

\section{Materials and methods}

\section{Case study site}

Praslin, the second largest island in Seychelles has a total land size of $38 \mathrm{~km}^{2}$ with an annual average temperature of $30^{\circ} \mathrm{C}$ and a minimum of $25^{\circ} \mathrm{C}$ (Etongo et al., 2020). Furthermore, annual average figures for rainfall maximum and minimum ranges between $292 \mathrm{~mm}$ and $140 \mathrm{~mm}$. According to the Seychelles Meteorological Authority (SMA), the yearly precipitation for Praslin during the last five years from 2020 to 2016 was $2803 \mathrm{~mm}, 2947 \mathrm{~mm}, 1990 \mathrm{~mm}, 2146 \mathrm{~mm}$, and $2080 \mathrm{~mm}$. Praslin has a population of 7,533 people and comprises two administrative districts: Baie Sainte Anne and Grand Anse. The main settlements are the Baie Ste Anne, Anse Volbert and Grand Anse. It was named Isle de Palmes by explorer Lazare Picault in 1744. Seychelles in general and Praslin in particular suffers from low economic diversification and vulnerability to external shocks, given its dependence on tourism and fisheries and fishery-related manufacturing (OECD, 2013).

Two types of soils prevail in the Seychelles: (i) ferralitic soil, commonly known as "la Terre Rouge" or red soil and originating from the weathering of granitic rock, is widely extended over the slopes, hills and mountains of the granitic islands: (ii) calcareous sandy (Shoiya series) soil exists on the small plateaus on the coast of the granitic islands and on the coralline islands (FAO, 2005). The case study location is found within the National Park and is a predominantly mountainous area around the Fond B'offay Watershed $\left(4.33807^{\circ} \mathrm{S}\right.$ and $\left.55.75368^{\circ} \mathrm{E}\right)$ on Praslin with active participation from TRASS to ensure the rehabilitation of the degraded forest areas (see Fig. 2).

The ferralitic soil type is the dominant soil that occurs at the Fond B'Offay Watershed area and also across other mountainous sites on Praslin Island (see Fig. 3). Despite the favourable climate conditions of rainfall and temperature that support tree growth, the forest landscape especially on mountainous areas dominated by boulders have not allowed sufficient accumulation of top soils. The soil humus layer is easily washed away given the dominance of steep slopes that are not properly covered by vegetation. In addition to the steep slopes, larger boulders are easily spotted on the mountainous landscape (see Fig. 3), and in some cases, they prevent the firm grip of tree roots into the soil. Forest fires date back to the last 70 years (Senterre (2009) documented a chronology of events) and it has become less frequent with the most recent on Praslin during the month of August 2020. TRASS have been involved in forest rehabilitation across the fire ravaged sites through domestic and internationally funded projects. The Fond B'Offay watershed is a Government of Seychelles (GOS) Adaptation Fund-UNDP Ecosystem based Adaptation (EBA) project site and the target indicator of forest rehabilitation within this project is 25 ha of degraded forest between 2014-2021 (UNDP, 2013). 


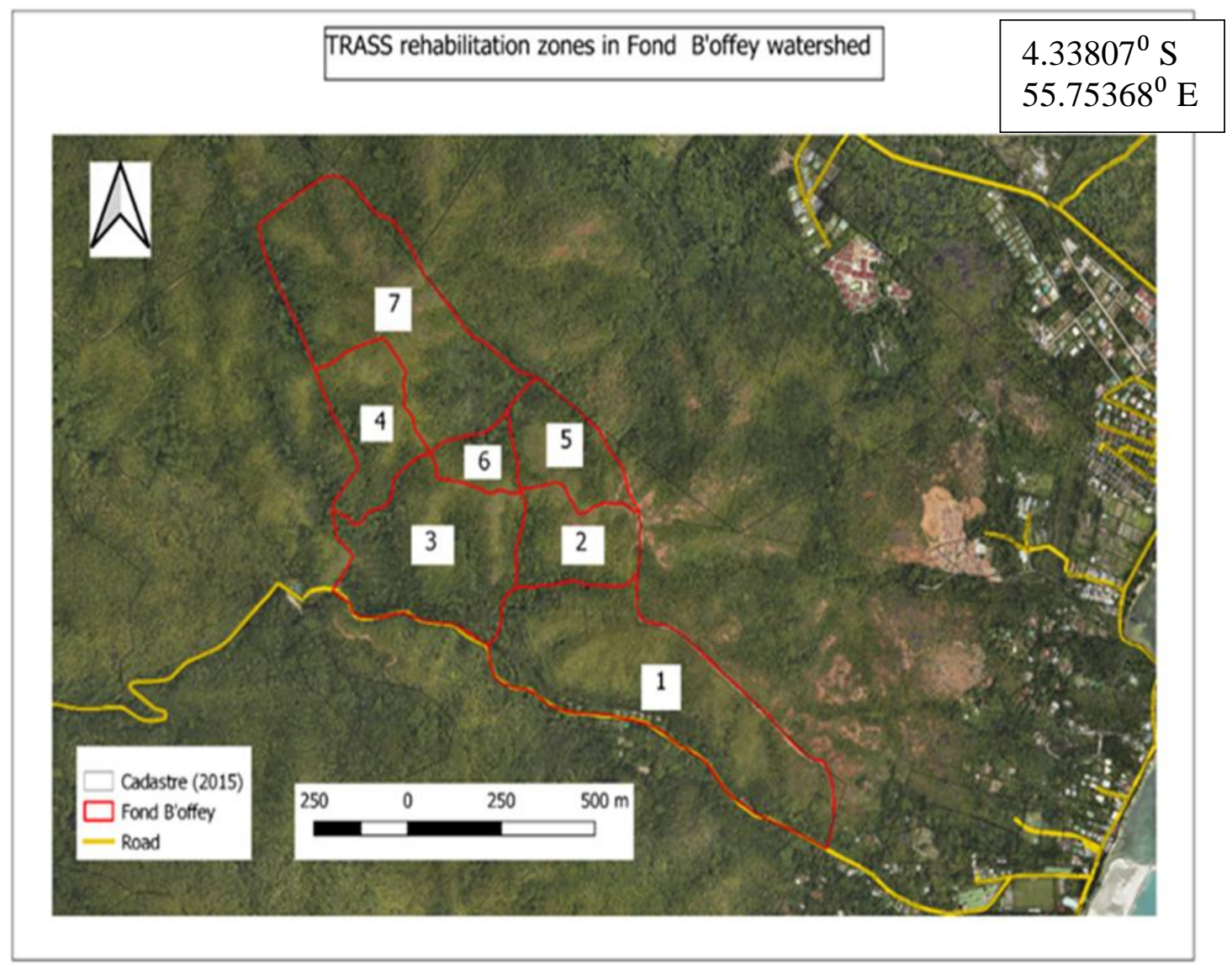

Figure 2. Different forest rehabilitation zones managed by TRASS at the Fond B 'Offay watershed

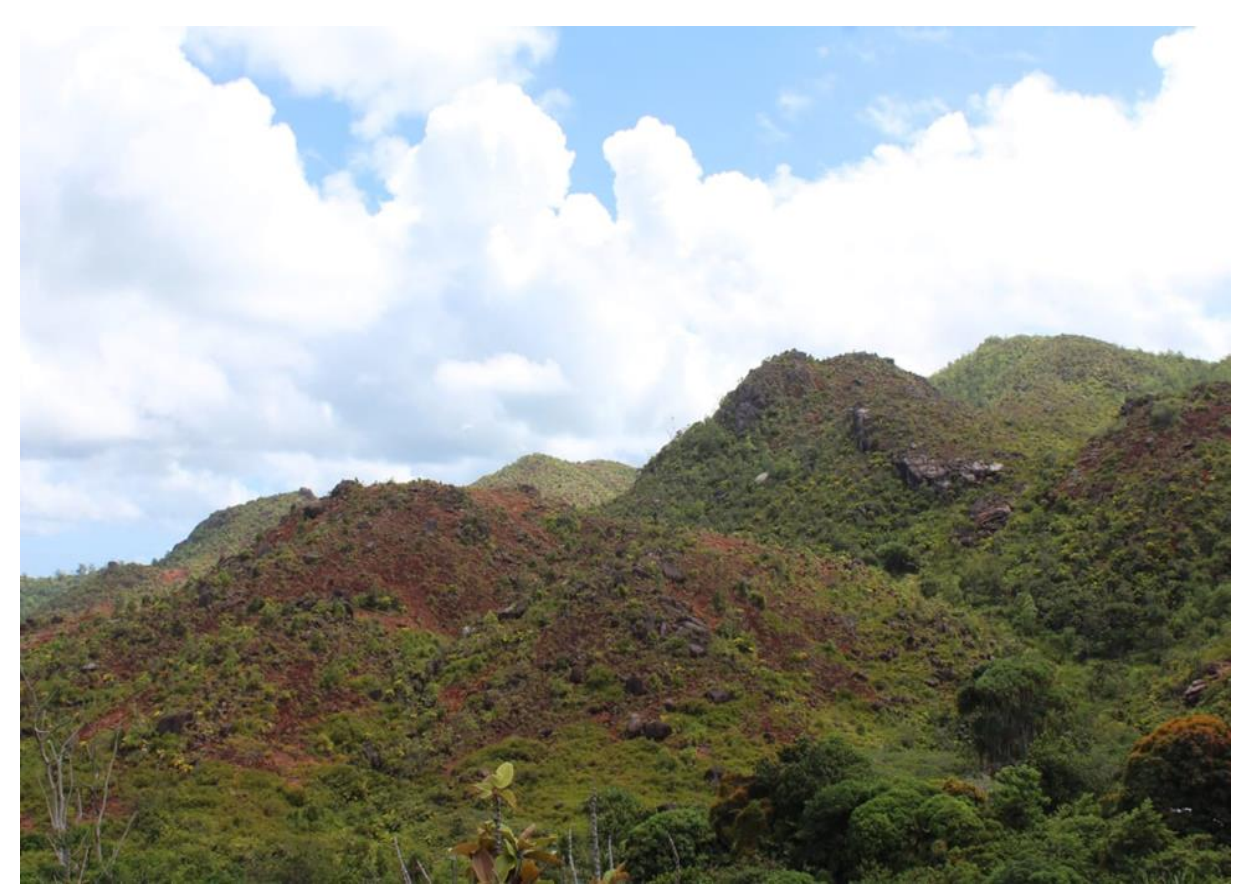

Figure 3. Ferralitic soil type on mountainous sites on Praslin that suffers from intense degradation. Photo credit: Daniel Etongo (Etongo et al., 2020) 


\section{Research design and data collection}

\section{Information from key informants and field observations}

This study began with a shared dialogue workshop (SDW) with opinion leaders from different organizations that are involved in forest rehabilitation on Praslin. The opinion leaders were representatives from the MACCE, SNPA, TRASS and community members. A SDW is a forum that brings academics as well as technicians, practitioners, community leaders, and household members together at regular intervals to identify challenges and obstacles to, and opportunities for, the participation of households and community members in the management of a natural resource (Etongo et al., 2018) and in this case - forest rehabilitation. Taking these criteria into consideration, three SDWs were conducted between the months of September to November 2020. These workshops were conducted entirely in the local vernacular (Creole). Some of the issues discussed were a list of tree species used in rehabilitation, type of land management techniques implemented, challenges encountered in rehabilitation activities, and capacity needs for forest rehabilitation.

The database of TRASS which include data on types and number of trees planted, number of hectares rehabilitated, number of participants during tree planting and rehabilitation activities also provided additional information. For a comprehensive lists of indigenous, endemic and exotic tree species planted by TRASS, see Appendix 1. Field observation at two of the rehabilitation sites occurred in the month of December 2020. The main focus during the field visit included the types of trees planted, the nature of the terrain (steepness of slope and accessibility), the layer of humus in the soil was also assessed visually, vegetation cover and extent of damage caused by fire with some photographs taken to support findings from the survey. Field observations can provide unique information, because it does not rely on other's verbal interpretations of situations, but on observation made while in the field.

\section{Sampling and data collection}

To successfully achieve the aims of this research, qualitative as well as quantitative data was collected from 180 households (from a total of 2490 households) on Praslin using the stratified random sampling technique in order to understand people's perception on issues pertaining to forest rehabilitation. The sampling was carried out in close collaboration with the National Bureau of Statistics (NBS) Seychelles given that NBS have a comprehensive database of households across the Seychelles. The two administrative districts of Praslin - Baie Sainte Anne and Grand Anse were considered as two separate strata for the sampling of households. This was followed by the identification of all Enumeration areas (EA) in the two main districts that amounted to 68 EAs in total. To interview householders from all of these EAs could have been time consuming and costly. Therefore, the EAs were later grouped according to regions, nine (9) in total with a random selection of 200 households corresponding to 95 and 105 householders in Grand Anse district and Baie Ste Anne district respectively (see Table 2).

In some regions, less respondents were reached given that a household member was not available at the time of the survey while others were unwilling to participate due to lack of time and in some cases for political reasons that their political party just lost an election. That notwithstanding, a total of 180 surveys were completed across the nine regions in both districts. The survey questionnaire was clustered in categories from socio-demographic data to benefits of forest rehabilitation, factors influencing 
household participation in forest rehabilitation, among other. Some examples of qualitative questions included (i) what do you think could be the cause of forest fire on Praslin? (ii) What do you think could be done to improve on the rehabilitation of fire ravaged forest lands on Praslin? For more details, see the supplementary questionnaires.

Table 2. Number of households surveyed across the nine regions in both districts on Praslin

\begin{tabular}{c|c|c|c}
\hline District & Region & $\begin{array}{c}\text { Total sampled } \\
\text { household }\end{array}$ & $\begin{array}{c}\text { Respondents reached and } \\
\text { interviewed }\end{array}$ \\
\hline \multirow{4}{*}{ Grand Anse } & Cherimont (Mont Plaisir & 40 & 30 \\
& Anse kerlan & 30 & 33 \\
& Amitie & 25 & 21 \\
\hline \multirow{5}{*}{ Baie Sta Anne } & Anse Boudin/Anse Lazio & 20 & 20 \\
& Zimbabwe & 14 & 10 \\
& Cote D'or & 26 & 22 \\
& Baie Ste Anne & 30 & 33 \\
& Moulignee Estate & 15 & 11 \\
\hline Total & & 200 & 180 \\
\hline
\end{tabular}

\section{Data analysis}

Descriptive and inferential statistics have been used to analyze the quantitative data. For the qualitative questions such as (i) perceived causes of forest fire on Praslin and proposed strategies to improve forest rehabilitation, these questions were analysed first by identifying main themes and assigning responses to their corresponding themes which was then coded for quantitative analysis. Regarding the determinants at the level of the households that influences participation in forest rehabilitation, the dependent variables are categorical - participants and non-participants in forest rehabilitation. Therefore, the logistic regression model was applied in order to understand the determinants at the household level that influence participation in forest rehabilitation activities. All analysis were performed using the Statistical Package for Social Sciences (SPSS) Version 20 and the results are presented in the form of tables and column graphs. A regression analysis is used to describe the relationship between a set of independent variables and a dependent variable. In this case, the dependent variable is participation in forest rehabilitation (with two groups - those that have participated, and those that have not) while the independent variables were gender of the household heads, age, schooling years, membership in a $\mathrm{CBO}$ and family size. For the multiple response questions, they were grouped using the multiple response function in SPSS and bar charts were produced to highlight the results in percentages. Lastly, Mean, counts and percentages were used to provide a summary statistics for the socio-demographic profile of the surveyed participants. The results are presented in bar charts and tables.

\section{Results}

\section{Socio-demographic profile of householders and perceived causes of forest fires}

The survey results showed that the mean age for householders at Grand Anse and Baie Ste Anne did not differ significantly. On the other hand, more females participated 
in the survey especially at Baie Ste Anne $(35.0 \%)$ in which the figure almost double that of male participants (see Table 3). The category "other employments" was mentioned by a relatively greater number of households (20.6\% for Grand Anse and $18.9 \%$ for Baie Ste Anne) and included those that are working with security agencies and other related activities within the tourism sector.

Table 3. Socio-demographic information of householders that participated in the survey

\begin{tabular}{c|c|c|c}
\hline & Grand Anse & Baie Ste Anne & TOTAL \\
\hline Age (mean) & 44 & 43 & \\
\hline Gender (household head) & & & \\
\hline Male & $41(22.8)$ & $33(18.3)$ & $74(41.1)$ \\
Female & $43(23.9)$ & $63(35.0)$ & $106(58.9)$ \\
\hline Main occupation (household head) & & & \\
\hline Farmer & $4(2.2)$ & $7(3.9)$ & $11(6.1)$ \\
Fisher & $1(0.6)$ & $11(6.1)$ & $12(6.7)$ \\
Business owner & $18(10.0)$ & $25(13.9)$ & $43(23.9)$ \\
Civil servant & $24(13.3)$ & $19(10.6)$ & $43(23.9)$ \\
Other employments & $37(20.6)$ & $34(18.9)$ & $71(39.4)$ \\
\hline Education (household head) & & & \\
\hline No formal education & $2(1.1)$ & $0(0.0)$ & $2(1.1)$ \\
Primary & $20(11.1)$ & $7(3.9)$ & $27(15.0)$ \\
Secondary & $23(12.8)$ & $38(21.1)$ & $61(33.9)$ \\
Post-secondary & $31(17.2)$ & $47(26.1)$ & $78(43.3)$ \\
University & $8(4.4)$ & $4(2.2)$ & $12(6.7)$ \\
\hline Lousehold dependency ratio & & & \\
\hline Medium & $36(20.0)$ & $30(16.7)$ & $66(36.7)$ \\
High & $24(13.3)$ & $29(16.1)$ & $53(29.4)$ \\
\hline Knowledge of TRASS activities & $24(13.3)$ & $37(20.6)$ & $61(33.9)$ \\
\hline Yes & $57(31.7)$ & $78(43.3)$ & $135(75.0)$ \\
No & $27(15.0)$ & $18(10.0)$ & $45(25.0)$ \\
\hline
\end{tabular}

The figures in parentheses represent percentages $(\%)$

In terms of educational level of the respondents, an estimated $84 \%$ have acquired secondary to university education while a miniscule $1.1 \%$ had no formal education and another $15.0 \%$ had completed just primary education in both districts. Information gathered from the resource persons during the SDWs indicated that education is free in the Seychelles up to post-secondary and scholarship opportunities are available for university studies locally and abroad. This further explains while majority of the respondents have acquired education at different levels. The household dependency ratio was spread across the three categories - low (36.7\%), medium $(29.4 \%)$ and $33.9 \%$ for high dependency ration (see Table 3). It is expected that householders with relatively higher dependency ratios are expected to be less active in forest rehabilitation activities given that the burden of the household is borne by the few adults of the working age group. Regarding knowledge on TRASS activities, $15.0 \%$ and $10.0 \%$ of 
respondents at Grand Anse and Baie Ste Anne mentioned that they were unaware of activities implemented by TRASS whereas $75.0 \%$ of respondents in both districts had knowledge on such activities (Table 3).

Causes of forest fires on Praslin were attributed mostly to ignition from cigarette butts as reported by $40.6 \%$ of the 180 respondents that participated in the survey (Fig. 4). This was followed by another $31.1 \%$ of respondent who were of the perception that the extended drought period during the dry season is the cause of forest fires on Praslin. Additionally, $13.3 \%$ of the respondents attributed the cause of forest fires to bee hunting for the harvesting of honey. The causes of forest fire based on information during the SDWs have not changed, but it is amplified by the extended drought period. However, the frequency of fire has changes from 1 to 2 occurrences during the last two decades compared to an average of 5 occurrences during the $60 \mathrm{~s}$ and $70 \mathrm{~s}$.

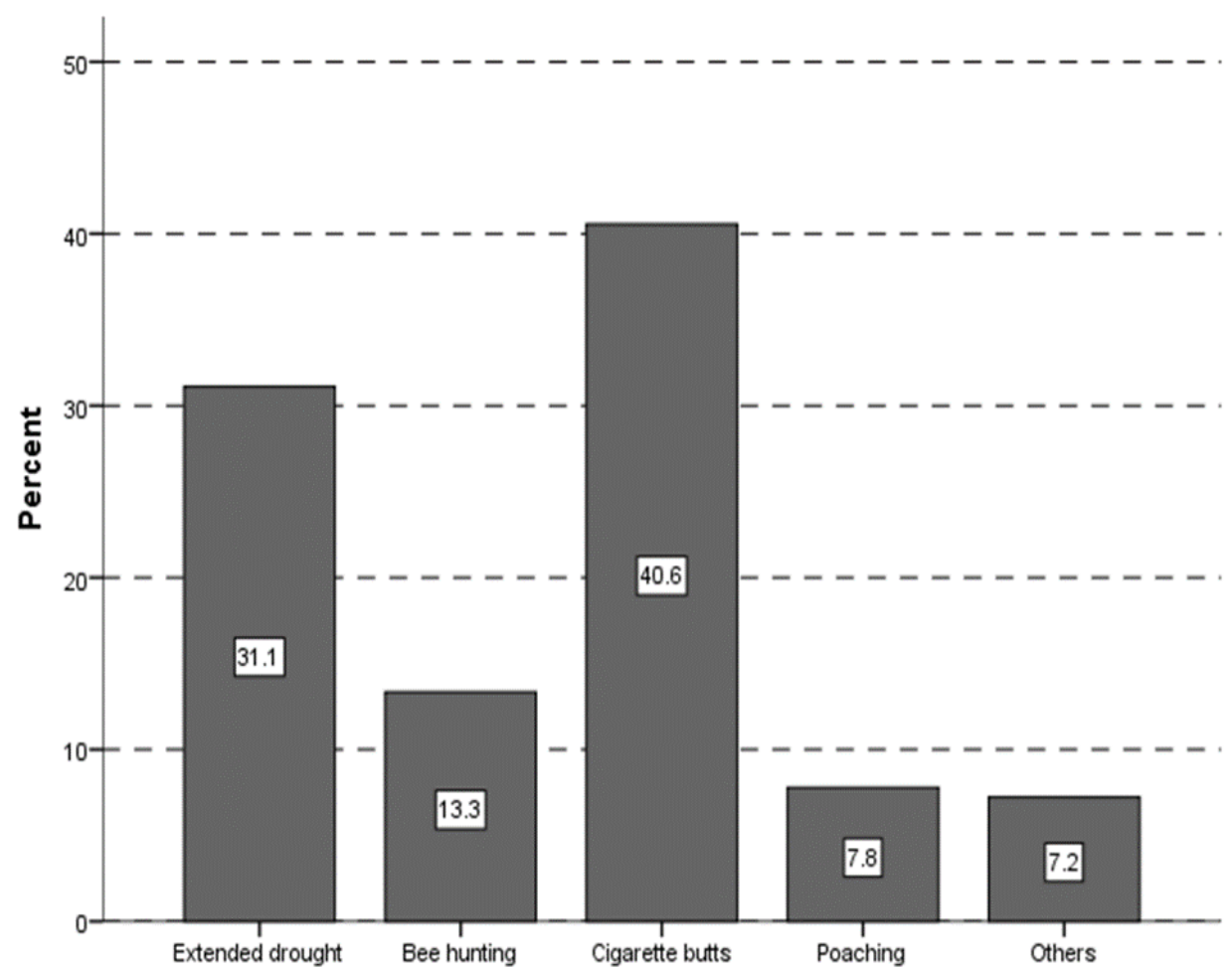

Figure 4. Causes of forest fires on Praslin Island based on local perceptions $(N=180)$

Information gathered from opinion leaders indicated that than $40 \%$ of the land area on Praslin was affected by forest fires while Curieuse Island was almost entirely burnt. Furthermore, opinion leaders were of the views that forest fires have reduced over the last three to four decades, but that the vegetation remains flammable and risks of forest fires is still a major concern especially in the face of climate change and variability. Therefore, dry weather conditions coupled with steep slopes and mountainous landscapes that experiences relatively stronger wind speeds create ideal conditions for forest fires to occur. The exposed top soil with its little organic matter based on field observation at the affected sites, then erodes easily by runoff after torrential rainfall. After losing the vegetative cover, the top soil and organic matter, these affected soils will crust and bake in the sun, and become rock-hard preventing the establishment of vegetation. 


\section{Determinants of household participation in forest rehabilitation}

Family size, age and gender does not influence household participation in forest rehabilitation. However, membership in a community-based organization (CBO) was significant at the 5\% level indicating that it did influence participation in forest rehabilitation (see Table 4). The number of schooling years of householders was not significant and that could be further explained that the level of education did not have an influence on the participation in forest rehabilitation. Participation in forest rehabilitation is not gender sensitive and this was supported by information gathered from the key informants. To further substantiate this claim, Figure 5 highlights the fact that both male and female of different age groups actively participate in tree planting activities as part of forest rehabilitation on Praslin. Forest fires on Praslin has a long history and there is a nation-wide awareness given that these incidents are reported via several News Papers, Radio and Television Stations and different social media platforms with a greater reach to community member. Seychelles is a Small Island State and information easily circulate around the communities; however, all other factors did not affect participation in forest rehabilitation except for membership in a CBO.

Table 4. Regression model of household determinants towards forest rehabilitation

\begin{tabular}{|c|c|c|c|c|c|c|c|c|c|}
\hline & \multirow[t]{2}{*}{ B } & \multirow[t]{2}{*}{ S.E. } & \multirow[t]{2}{*}{ Wald } & \multirow[t]{2}{*}{ df } & \multirow[t]{2}{*}{ Sig. } & \multirow[t]{2}{*}{$\operatorname{Exp}(B)$} & \multicolumn{2}{|c|}{$\begin{array}{c}\text { 95\% C.I.for } \\
\text { EXP(B) }\end{array}$} \\
\hline & & & & & & & & Lower & Upper \\
\hline \multirow{6}{*}{ Step $1^{\mathrm{a}}$} & Gender & -.105 & .311 & .113 & 1 & .736 & 901 & .489 & 1.658 \\
\hline & Age & .004 & .012 & .111 & 1 & .739 & 1.004 & .981 & 1.027 \\
\hline & SchoolYears & .079 & .074 & 1.136 & 1 & .287 & 1.082 & 936 & 1.252 \\
\hline & $\mathrm{CBO}$ & 1.185 & .619 & 3.671 & 1 & $.055 * *$ & 3.271 & 973 & 10.996 \\
\hline & FamSize & .035 & .044 & .640 & 1 & .424 & 1.036 & .950 & 1.130 \\
\hline & Constant & -1.305 & 1.296 & 1.014 & 1 & .314 & .271 & & \\
\hline
\end{tabular}

${ }^{a}$ Variable(s) entered on step 1: Gender, Age, SchoolYears, CBO, FamSize

$* 0.1(10 \%), * * 0.05(5 \%)$ and $* * * 0.01(1 \%)$ level of significance

Of the 96 respondents that are yet to participate in forest rehabilitation attributed their lack of participation to the following reasons (Fig. 6). Chief among these reasons was the lack of information on TRASS activity especially for tree planting as reported by $63.5 \%$ of the 96 respondents. This was followed by time constraints $(61.5 \%)$, access to sites/the difficult nature of the terrain $(45.8 \%)$, health related issues $(37.5 \%)$ and a miniscule $13.5 \%$ reported distance to sites as the major factor that prevent their participation in forest rehabilitation activities being undertaken by TRASS (Fig. 6). Social media platforms, networking with other organizations and verbal communication are the medium used by TRASS to disseminate information pertaining to tree planting activities. Information gathered from TRASS showed that regular Facebook posts is the most used medium of communication. However, most of the community members that are yet to participate in forest rehabilitation were of the opinion that they are not on social media and hardly get timely information on planned tree planting activities. Therefore, alternative communication strategies that are relevant to the non-social media users will be important to improve engagement among this group of community member. Another reason mentioned by some of the community members who had prior 
access to activities organized by TRASS, also cited the timing of these activities occurring during the weekends as an impediment. While some of the respondents mentioned that they work even during weekends especially on Saturday mornings, for others, weekends were most preferred for buying groceries and performing other household chores.

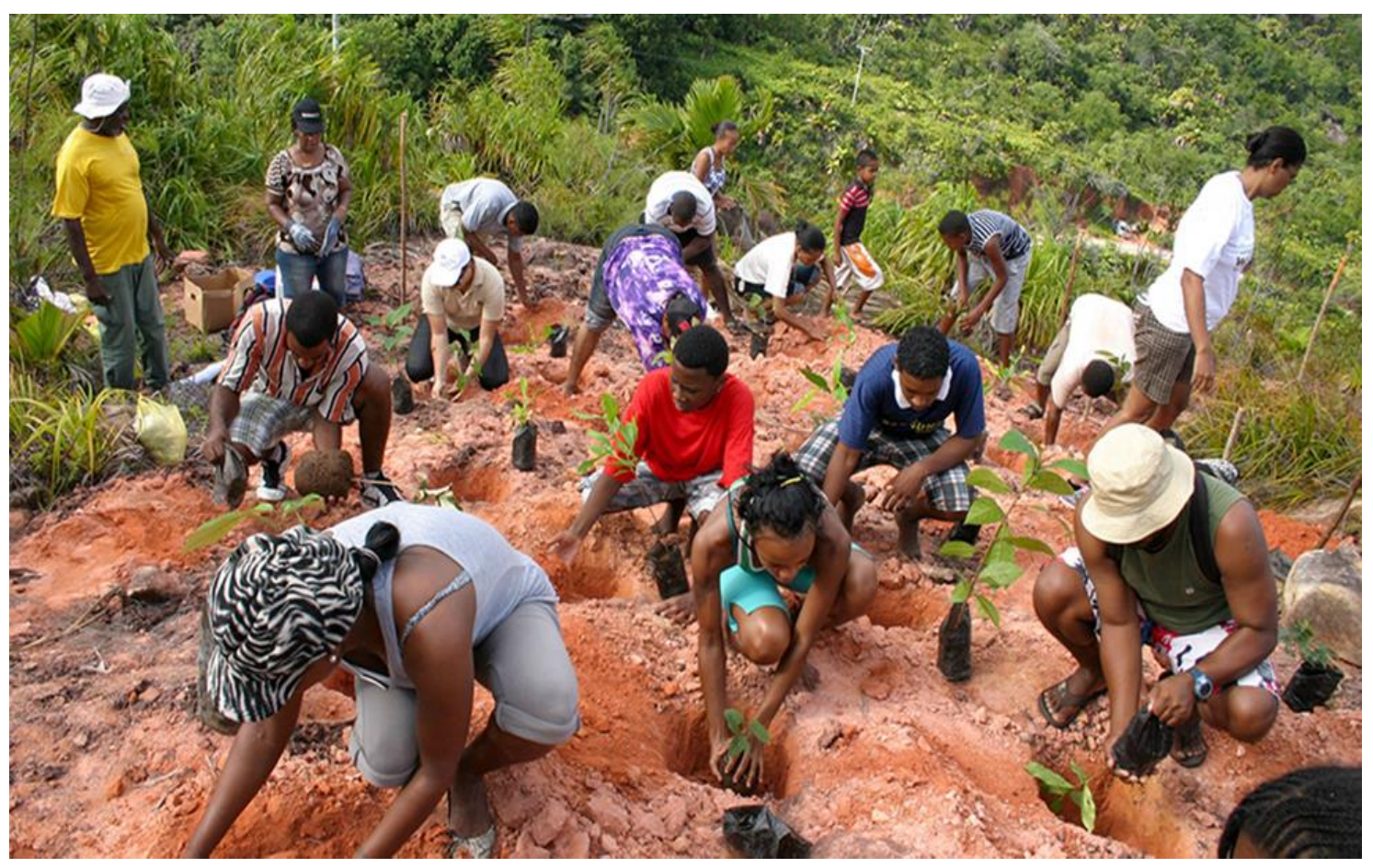

Figure 5. Both males and females of different age group participating in tree planting activity on Praslin organized by TRASS. Photo credit: Elvina Henriette (GEF, 2020)

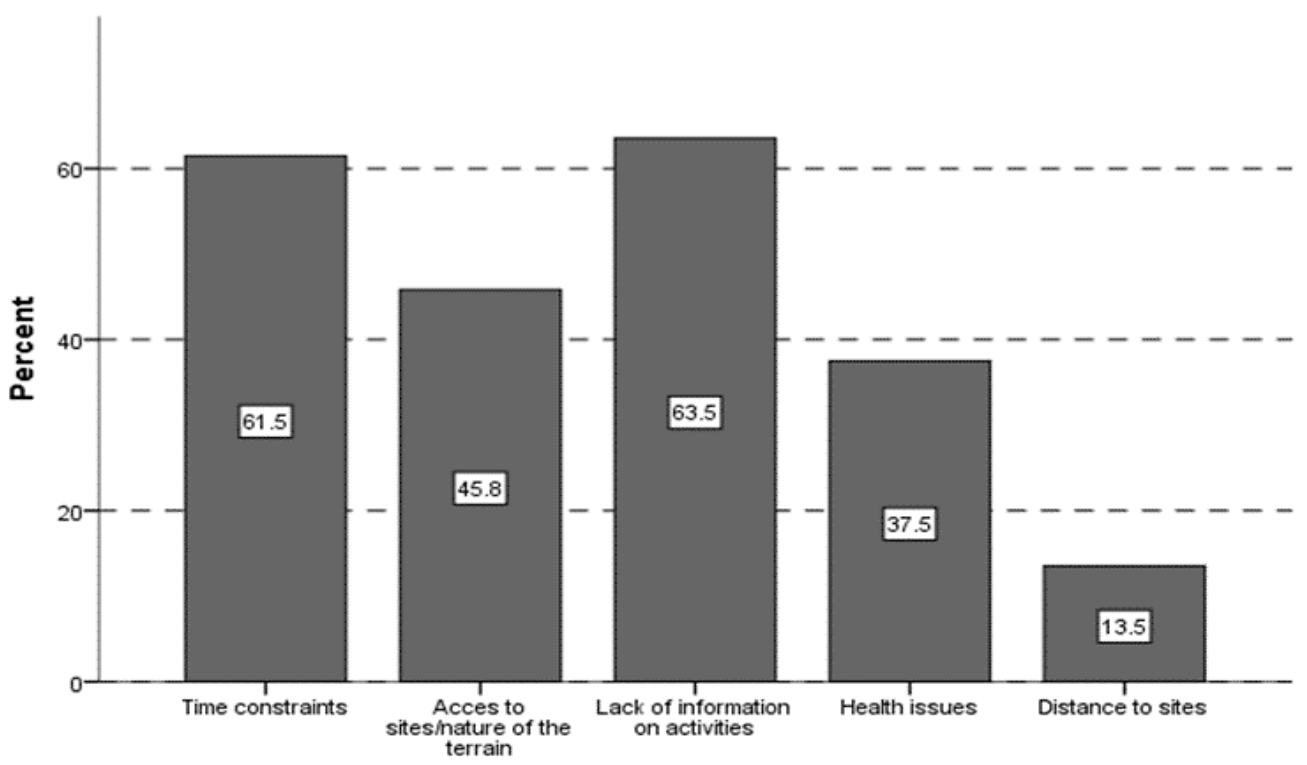

Figure 6. Factors that prevent community member from participating in forest rehabilitation activities. Result is based on the 96 (53.3\%) out of the 180 community members that have not participated in forest rehabilitation. Multiple responses with percentage $>100$ 
Furthermore, another important reason mentioned by some of the community members and also observed during field visits is that the nature of the terrain is too steep to the extent that some form of support is needed to walk from one part of the forest landscape to another. To corroborate this view regarding the steep nature of the terrain making it difficult to access specific sites, a visit to one of the project sites at Fond B'Offay by the EBA project team further revealed the issue of accessibility. In some cases, a polyethylene rope is needed to access those sites with steep slopes (Fig. 7). Therefore, the nature of the terrain is the third most important factor mentioned by community members that prevent their participation in forest rehabilitation.

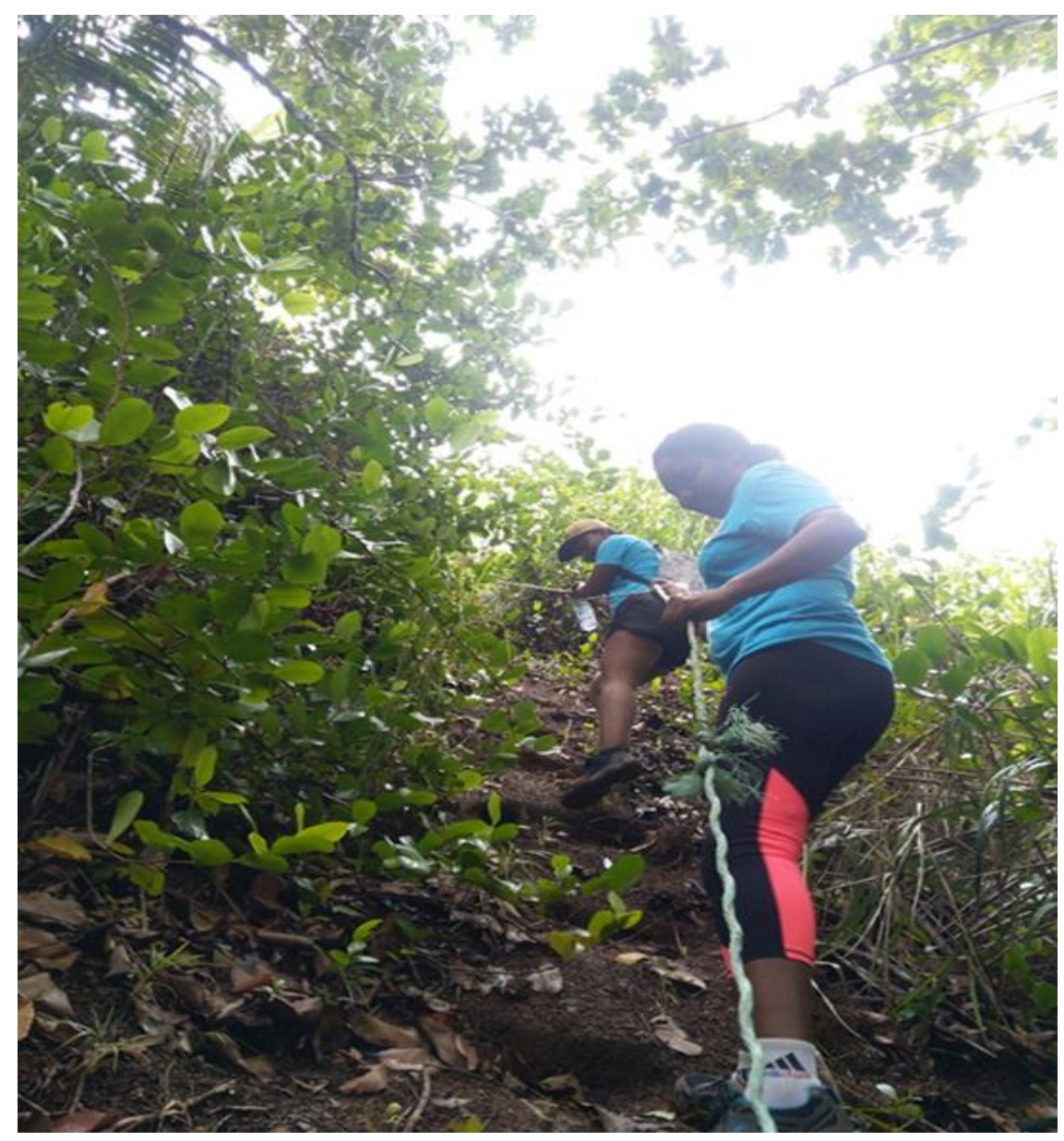

Figure 7. A visit to the forest rehabilitation site by the EBA project team with the use of a polyethylene rope in order to access steep sites of the forest landscape. Photo credit: Vicky Stravens (TRASS; 2020)

\section{Community participation across the three stages of forest rehabilitation}

The three stages of forest rehabilitation considered in the current study include the following: planning, implementation and monitoring stage. Data collected and summarized in Appendix 2 shows that majority of the community members were involved in the implementation stage with activities such as transportation of tree seedlings and tree planting. Though TRASS benefit from the support of domestic and international donors, the planning and monitoring stages are still dominated by its 
members with a minuscule level of participation of the MACCE, SNPA, EBA Seychelles project, other NGOs and volunteers at these stages. Three interrelated activities in the implementation stages that recorded most responses are transportation of seedlings, tree planting and participation in training programs. A short training as was observed during field visit is usually provided prior to tree planting by TRASS in order to ensure a greater success rate of planted trees. Those participating in tree planting benefits from such trainings and they also transport the seedlings from the assembly point to the planting sites. The activity that received the least responses is the cutting of tracks which require a lot of physical labour (see Appendix 2). However, this activity according to key informants have been performed jointly at some of the rehabilitation sites by members of TRASS, SNPA and the Praslin Watershed Committee (WSC). Within the context of the EBA project for Seychelles, the WSC is a $\mathrm{CBO}$ given that its composition is entirely made up of community member with the mandate to led activities such as mangrove restoration, tree planting on degraded lands, protection of watersheds, and raising awareness across their communities on the need to protect and restore forest ecosystems and the multiple benefits it provides.

\section{Perceived benefits and challenges encountered in forest rehabilitation}

In general, community members perceive a lot of benefits that are linked to forest rehabilitation. The first four benefits based on the survey results include soil protection services from erosion, biodiversity conservation, landscape improvement (98.3\%) and water quality and quantity (90\%) as indicated in Figure 8. The multiple benefits mentioned by community members goes to show that they understand the importance of forest and the ecosystem goods and services it provides. Perceived benefits were viewed more in-kind rather than forest income. Forests is more than just trees and provide multiple benefits for local livelihoods in the form of food, energy, income, to environmental protection including carbon habitats that are important to climate change mitigation.

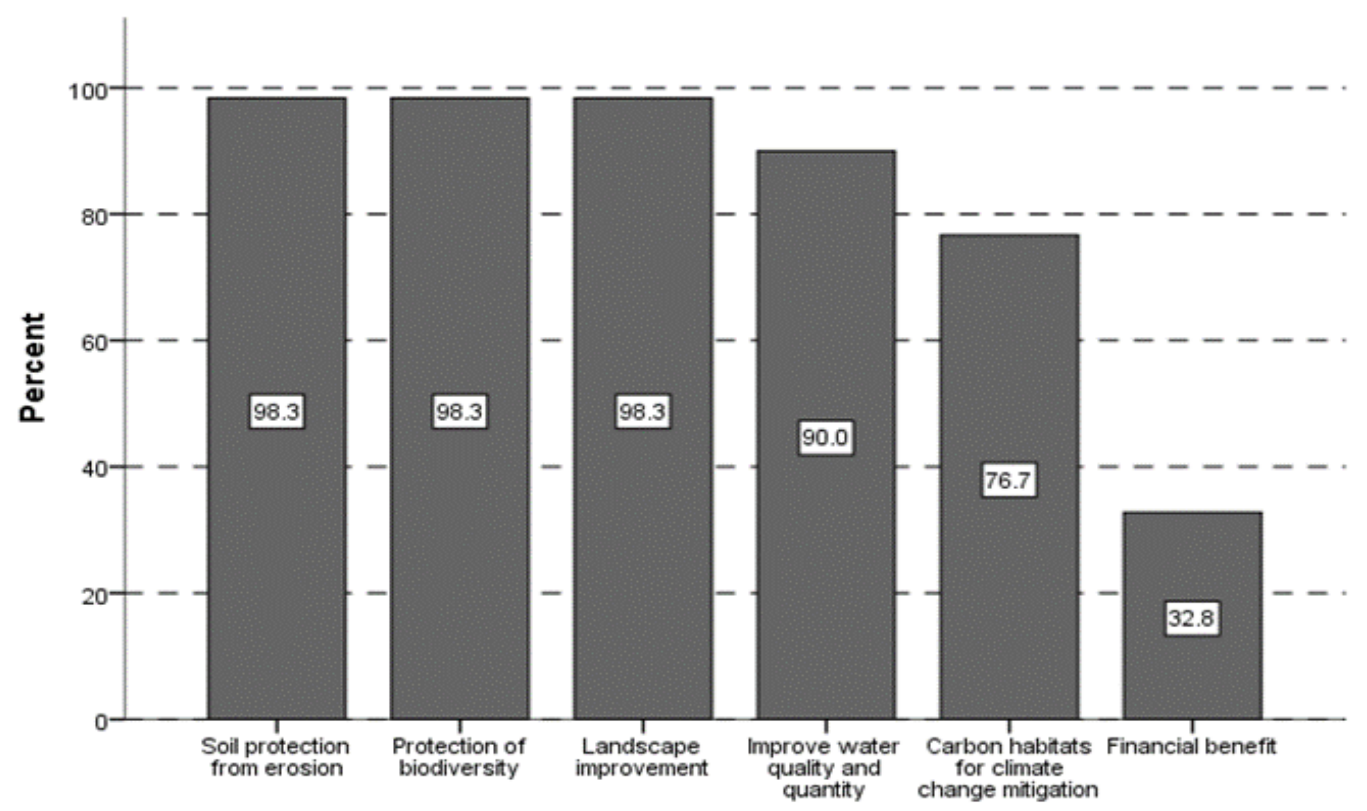

Figure 8. Benefits of forest rehabilitation as perceived by community members. Multiple response question with overall percentage $>100$ 
The challenges reported by respondents include technical and human capacity needs, availability of seedlings, impacts of climate change among others. Technical challenges that were prominent among those mentioned by community members are soil erosion reported by $64.1 \%$, inadequate knowledge and skills $(61.8 \%)$ preventing the effective rehabilitation of forest on Praslin, shortage of seedlings $(61.2 \%)$, and $47.6 \%$ for those that mentioned recurrent forest fires (Fig. 9). Shortage of seedlings is a contrary view community members given that SNPA has two well-equipped nurseries at New Comb and Fond B'Offay with the active involvement of its staffs to grow stocks, harvest seeds and propagate them. TRASS on the other hand has a main nursery behind its office at Fond B'Offay which has an average of over 15,000 seedlings at any given time, most of the work is done by TRASS members and before the Covid-19 pandemic engaged volunteers or other community groups mainly during the weekends. It is through the involvement of volunteers almost every Saturday that TRASS managed to boost up its nursery stocks. However, TRASS and SNPA both agree that one of their main challenges is getting enough participants to cover all the area that needs rehabilitation on Praslin. SNPA further expresses concerns that their work force is not only limited but ageing and there is a need to employ more youths. Other challenges mentioned by community members pertain to governance issue that can be translated to land and tree tenure security and also the success rate of the planted trees given the steep nature of the terrain and the relatively small humus content of the top soil especially on mountainous slope with fewer trees.

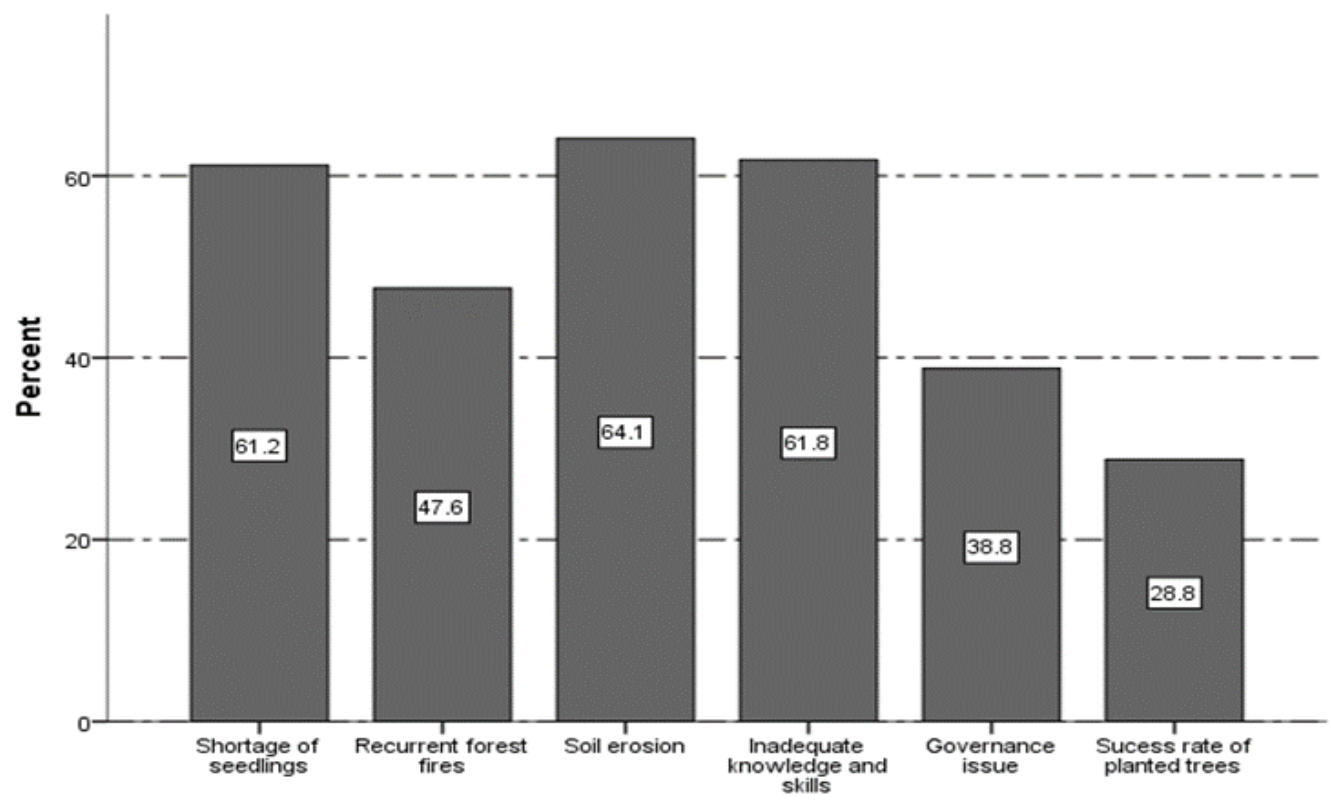

Figure 9. Challenges encountered by community members in forest rehabilitation

\section{Multiple response question with overall percentage $>100$}

\section{Proposed strategies to improve forest rehabilitation}

A wide range of strategies were proposed by community members as options to improve forest rehabilitation activities on Praslin. Chief amongst them included the following: i) to improve on awareness and education campaigns $(63.3 \%)$, ii) to produce 
more seedlings of native tree species for planting $(63.3 \%)$, and iii) more manpower needed $(60.6 \%)$ especially for cutting of tracks, weeding, transportation of seedlings, planting, among others (see Fig. 10). Two other strategies that were mentioned are improvement in community participation and also to develop an efficient monitoring and evaluation system as reported by $52.2 \%$ and $49.4 \%$ of the respondents respectively (Fig. 10). Failures of past tree planting efforts on degraded forest areas in Praslin has been associated with low fertility of soil, lack of technical skills as well as constraints imposed by the nature of the terrain and recurrent forest fires. Opinion leaders from TRASS proposed that some best practices already implemented should be up-scaled to other sites. These include (i) the application of $1 \mathrm{~kg}$ of humus to newly planted tree seedlings, (ii) the use to stones to construct an erosion control barrier for seedlings potted on steep slopes or at sites that could easily be affected by erosion to prevent seedlings from being washed away, and (iii) a short training provided prior to tree planting to ensure best practices are followed.

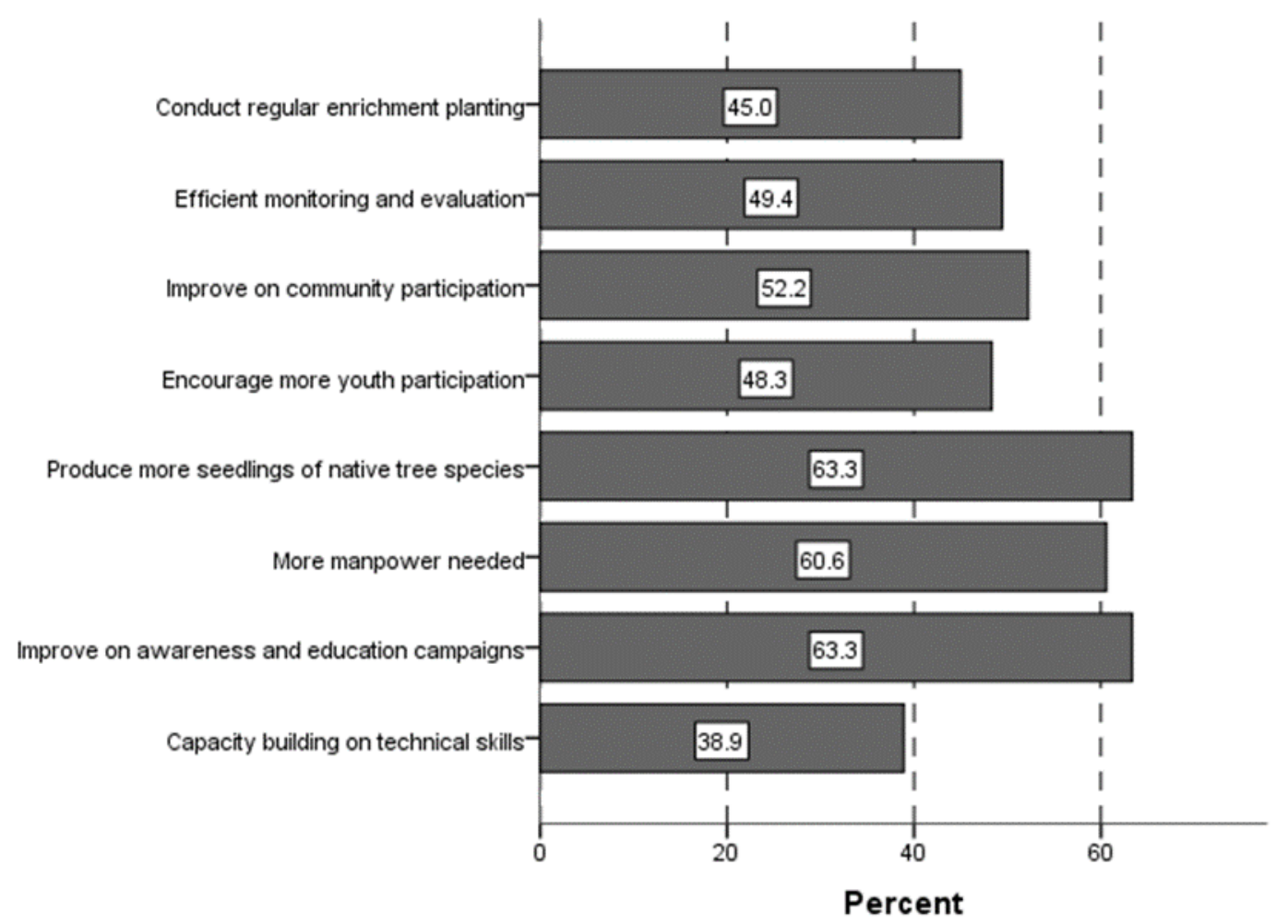

Figure 10. Proposed strategies by community members to improve forest rehabilitation. Multiple response question with overall percentage $>100$

\section{Discussion}

According to a featured story by the Global Environment Facility (2020), the impacts of climate change and environmental degradation are increasingly evident on Praslin Island and the predominantly mountainous landscapes bear evidence of degradation due to anthropogenic and climate-induced forest fires intensified by the extended period of drought. The implication is that leaf litter become combustible due to the extended drought and create a favorable condition for fire to persist when such materials are ignited by cigarette butts or other drivers. Two studies in Seychelles (Senterre, 2009; 
Kapisen, 2008) corroborate the view that the most important factors that determine the impact of forest fire in Seychelles are the depth of the leaf litter layer, the amount of flammable plant species such as the fern Dicrapnopteris linearis and the intensity of the fire. According to this study, when there is not much leaf litter on the ground, the fire passes quickly and some of the native palms survive.

The Global Environment Facility (2020) further reported that bush fire is the main threat to the unique forest ecosystem on Praslin. Also, the long and harsh drought periods intensified by climate change increases the risk of their occurrence as well as intensity once alight. It should be noted that Praslin's La Hauteur watershed in the Midland region suffered from 12 recorded human-induced forest fires between 1996 and 2008. Furthermore, the year 2008 witnessed two remarkable forest fires based on the extent of damage caused - at Fond d'Albaretz on Praslin, which affected 4.2 ha of prime native vegetation, and the other at the summit of Ste Anne Island, where some 40 ha was burned, including large areas with endemic palms and shrubs (Kapisen, 2008). A complicating factor is that most burned, severely degraded land is privately owned and private land owners are required neither to rehabilitate degraded lands nor to provide government with access for land rehabilitation (MEECC and UNCCD, 2018).

Regarding the determinants that influenced household participation in forest rehabilitation activities is linked to membership in a CBO. This result can be attributed to TRASS approach of working in collaboration with CBOs in forest rehabilitation activity which is a common approach that yield better outcome as highlighted by another study in Nepal (Gurung et al., 2013). However, the results further revealed that community members registered greater participation in the implementation phase rather than the planning and monitoring phases of forest rehabilitation. A much greater engagement of different stakeholders in the implementation phase spanning from the private sector, the government, NGOs and CBOs in forest rehabilitation has been made possible by the TRASS that has enabled tree planting capacity to increase over the years. For example, tree planting occurred on 5 ha of land as part of the forest rehabilitation initiative between the year 2016-2017 and another 18 ha between 20192020 implemented by the TRASS within the framework of the Ecosystem Based Adaptation (EBA) Seychelles Project. Over 20 volunteer organizations and 1,300 community members have benefitted from both projects to date. The community has also increased its resilience and ability to adapt to climate change. A core group of 12 individuals, in addition to a peripheral group of 20, were trained to transfer knowledge and know-how to the wider community. Through training and upskilling initiatives, local community capacity has been enhanced to ensure that they continue towards the end goal of developing, implementing, and sustaining their own solutions to current problems (GEF, 2020). The importance of forest rehabilitation was reiterated by one of TRASS volunteers as shown below:

"Through the project, I not only learned plant propagation techniques, I was also able to improve my livelihood and household income by earning additional income from plant preparation."

Such expression goes to reaffirm that community engagement in forest rehabilitation enhances skills and also provide financial benefits even to non-members of the core organization driving the initiative - a view supported by Blay et al. (2008). Another study in the Seychelles also mentioned continuous engagement with schools and local communities is an effective way to pass on relevant information and raise awareness on sensitive issues regarding management of forests (Senterre, 2015). 
The EBA project provided funding for the rehabilitation of fire ravaged forest lands on Praslin's Fond B'Offay watershed which also led to the creation of the Watershed Committee. Given the nature of the terrain and soil types, forest rehabilitation was a learning-by-doing process and that explains the relatively small area that was rehabilitated during phase 1 of the EBA project. In addition to implementation of experimental trials which is time consuming, resource persons from TRASS also mentioned that getting the right contractors on-board was a major challenge because not all of them could work in the burnt, baked sun, dense shrubs and steep terrain. However, lessons learnt during phase 1 led to the development of best practices and coupled with greater community participation resulted to 18 ha of land rehabilitated during phase 2 of the project as opposed to 5 ha during phase 1 . Community involvement through volunteerism is considered a priority for tree planting activities while members of the TRASS prepare the planting strips and grow nursery stocks. Therefore, good collaboration between stakeholders and communities provides greater success in forest rehabilitation on Praslin - a finding supported by another study from Zimbabwe (Matsvange et al., 2016).

In terms of benefits to community members, forests are known to boost fresh water storage through the root system of plants that allow for effective filtration of water (Thompson et al., 2011). However, an earlier study in Seychelles documented historical evidence supporting the importance of forest in providing livelihood benefits especially as a source of income for the country prior to independence. For example, $40 \%$ of the country's GDP was derived from the agricultural sector in 1970 through the export of copra and cinnamon. During this period, both the government and private companies engaged in exportation of forests products such as timber, Coco-de-mer, cinnamon and palm hearts which in turn created several local employment opportunities. With the fastgrowing tourism industry in the 1990's, pressure was released from forestry-related activities (Emerton, 1997), enabling the transitioning from agriculture and forestry to tourism and fisheries dependent economy. Such a transition in the economy has meant that the forestry sector is generally perceived as marginal with its GDP contribution, including wood industries estimated at $0.4 \%$ (MEECC and UNCCD, 2018). That notwithstanding, the forest ecosystem continues to provide several indirect economic and environmental benefits on Praslin and elsewhere in the Seychelles. For example, the extremely vulnerable water supply is highly dependent on the vegetation cover provided by the forest (MEECC and UNCCD, 2018).

Despite the benefits provided by forest rehabilitation to local livelihood and the environment in terms of ecosystem goods and services, community members also mentioned some of the challenges encountered in the forest rehabilitation process. Technical challenges manifesting in the form of inadequate knowledge and skills for tree planting on steep slopes often covered with boulders and coupled with soil erosion were of greater concern. Therefore, specific technical skills and resources are needed for the rehabilitation of upland forests that in some cases has proven more difficult than the coastal and lowland zones - a finding that is supported by another study conducted in Seychelles (Kapisen, 2008). In addition, climate variability and change are another challenge that confront forest rehabilitation in Seychelles with too much rainfall and droughts during across different years. One of the respondents reported that "this year 2020 we faced challenges with heavy rainfall down steep slopes uprooting and carrying away plants in some instances while in some cases, seedlings were deeply buried into the soil by eroded sediments. Hence, a lot of maintenance to remove sediments from 
around the plants and also maintaining the stone barriers constantly that act as erosion control barriers. Another problem that we have notice is the proliferation of invasive native creepers which covers and strangles seedlings especially during the early stages of growth". Another manifestation of rainfall variability is drought which sometimes occur over an extended period than usual during the dry season. Dry spells also create conditions for fire to spread quickly and in some cases due to negligence especially during slash and burn agriculture, ignition from cigarette butts, bee farming, among others that cause fire which easily spreads in the forest (Etongo, 2021). According to the same study, landslide also pose a problem to the health of the forest. For example, landslides create gaps which are invaded by invasive alien species (IAS) such as Albizia and Clidemia which compete and overgrow native species.

Some suggestions were proposed by community members in order to improve forest rehabilitation activities on Praslin. More awareness and education campaigns, the production of more seedlings of native tree species and additional manpower were the three most reported strategies. The lack of monitoring associated with little manpower from the responsible ministry and other relevant stakeholders such as the Seychelles National Parks Authority (SNPA) has also contributed to a low positive outcome regarding previous rehabilitation activities (Seychelles News Agency, 2020). The role of contractors seems to have diminished over time especially after the creation of the TRASS eleven years ago. On the other hand, government institutions such as the SNPA and MACCE work closely with TRASS that already have a wider reach to community members. In general, local community members on Praslin are more involved in forest rehabilitation when compared to other actors such as hired contractors.

In addition, improvement towards community participation also featured prominently which could partly be linked to better communication on TRASS planned activities especially to people not using social media, on the one hand, and creating an enabling environment for ownership that will motivate participation at the planning, implementation and monitoring phases of forest rehabilitation. Information gathered during the SDWs from TRASS representatives stated that "We also want to develop initiatives with economic benefits e.g. beekeeping on rehabilitated sites, agroforestry, trails for tour guides but funding still remains a major constraint". Furthermore, the creation of the watershed committee was cited as a step in the right direction that will enhance community participation and also develop skills through peer-to-peer trainings. Wekesa (2017) also reaffirmed that community involvement in forest rehabilitation can develop skills and create employment opportunities for locals. However, it is inconclusive whether financial incentives will increase the level of participation of community members in forest rehabilitation and at what stage. As such, further study is needed given that forest rehabilitation offers a wide range of benefits, the majority of which provides indirect economic benefits.

\section{Conclusions}

This study demonstrated that the predominant causes of forest fires on Praslin based on the perceptions of community members was ignition from cigarette butts followed by an extended drought period during the dry season. In some instances, the fire ravaged forests after losing its vegetative cover and soil organic layer, will crust and bake under the scorching sun and become hard thereby presenting a challenge to forest rehabilitation. The influence of climate and the loss of plant biomass implies that forest 
rehabilitation activities are important to Sustainable Development Goals 13 and 15 Climate Action, and Life on Land.

Forest rehabilitation requires the active participation of community member whose engagement in the process could be passive or active with the influence of several factors at play ranging from economic, socio-cultural, and institutional among others. Membership in a CBO was the only determinant at the household level that was significant regarding participation in forest rehabilitation while other factors such as household size, age, gender and number of schooling years were not. Therefore, communication channels that can provide access to information regarding planned activities of TRASS to non-social media users through different platforms such as News Papers, Schools, Radio and Television Stations should be considered as strategies to reach a wider proportion of community members. However, resource persons from TRASS did mentioned that these communication platforms have been used in the past but did not prove effective and hence not cost effective.

Both males and females of different age groups including teenagers participated in forest rehabilitation. Forest rehabilitation is a process and not an activity of which majority of the community members were mostly involved in the implementation phase participating in the transportation of tree seedlings and tree planting. Some community members do participate in plant propagation given that they have acquired trainings provided by TRASS from which additional income are derived. However, majority of the householder perceived in-kind benefits provided by forest rehabilitation through the provisioning of ecosystem goods and services such as soil protection services from erosion, biodiversity conservation especially for native tree species, landscape improvement and the protection of watersheds. Another important benefit cited was the creation of the Praslin Watershed Committee within the framework of the EBA project. Members of this committee have benefited from basic trainings to ensure the continual implementation of best practices in forest rehabilitation.

Furthermore, community members also mentioned the lack of specialized skills to enable the effective rehabilitation of specific sites that are predominantly mountainous with limited access due to very steep slopes. Therefore, technical challenges manifesting in the form of inadequate knowledge and skills for tree planting on very steep slopes were of greater concern especially those covered with boulders and also exposed to soil erosion. This reinforces the point that forest rehabilitation needs to be adaptive to prevailing local conditions and it is a learning-by-doing process through adaptive management in order to develop best practices that can ensure greater success. The phase 1 of the EBA project on Praslin clearly demonstrated this in which just 5 ha of forest was rehabilitated as opposed to 18 ha during phase after which some best practices were developed based on challenges encountered in phase 1. Currently, TRASS is conducting an erosion control experiment in order to determine soil loss under two scenarios - land with tree cover, and land without tree cover with plots established on same side of the slope and at the same inclination. Such an experiment will provide quantitative information and recommendations on soil loss from erosion on the one hand, and effective soil and water conservation techniques on the other hand, to be implemented on mountainous forest landscapes. Recommendations for future studies are needed in the following key areas as follows: (i) factors affecting the survival of tree seedlings on rehabilitated lands, (ii) impact of forest fire frequency on tree diversity and species regeneration, (iii) does tourism affects the frequency of forest fires, and (iv) a multi-criteria analysis of ecosystem services derived from rehabilitated forests. 
Lastly, some of the strategies for improvement as suggested by community members included awareness and education campaigns, more manpower needed especially during the cutting of strips in dense shrubland for planting, to develop an efficient monitoring and evaluation system, conduct regular enrichment planting, eradication of invasive species, and also greater involvement of community members at the planning stage of forest rehabilitation. Further strategies for improvement have been proposed by resource persons from TRASS who were part of the SDWs. One of the strategy that seems to have been tried in the past and has proven to increase motivation of community members to participate in forest rehabilitation is called the "treat system". According to TRASS, "volunteers receive points whenever they participate in our activitieas and the volunteers with most points are favoured to benefit from 'treats' such as an island trip, a boat trip, international training etc. This works very well because it provides incentives to volunteers as they look forward to the 'treat' and compete amongst themselves for most points. But managing this is quite a challenge if there is not someone totally dedicated to it". Another strategy proposed by TRASS is to continue to engage school children which is seen as a good way forward. One of the respondents stated that "we have proof of kids who are now young adults working in the field of environment after growing up with TRASS. Kids also bring along their parents hence having more participation". Finally, TRASS proposed another financial incentive mechanism through a different lens and mentioned that "another strategy TRASS would like to work on is one involving economic benefits like beekeeping, tour guiding, agrotourism and agroforestry by having a sort of cooperative where people who participate to rehabilitate degraded lands via the above-mentions approaches receives financial benefits from these activities.

Acknowledgements. We would like to thank the National Bureau of Statistics (NBS) Seychelles for guiding the sampling process based on available information from its comprehensive database of households across the Seychelles. The contributions of resource persons from the TRASS, MACCE, SNPA and all the community members that participated in survey, are greatly acknowledged. Lastly, we are thankful to the following students in the Environmental Science Program at the University of Seychelles who participated in the household interviews in the person of Maryssa Samedi; Bianca Marzocchi; Kelsy Gill; Alisha Belle; Kelly Etienne; Elgin Créa; Larrisha Serret; Louisette Hoareau.

\section{REFERENCES}

[1] Agarwal, B. (2001): Participatory exclusions, community forestry, and gender: an analysis for South Asia and a conceptual frame-work. - World Development (29): 16231648 .

[2] Arnstein, S. R. (1969): A ladder of citizen participation. - Journal of the American Institute of Planners (35): 216-224.

[3] Bagdi, G. L., Kurothe, R. S. (2014): People's participation in watershed management programmes: evaluation study of Vidarbha region of Maharashtra in India. - International Soil and Water Conservation Research 2(3): 57-66.

[4] Ballet, J., Ko, K. J. M., Komena, K. B. (2009): Co-management of natural resources in developing countries: the importance of context. - Economie Internationale (4): 53-76.

[5] Blay, D., Appiah, M., Damnyag, L., Dwomoh, F. K., Luukkanen, O., Pappinen, A. (2008): Involving local farmers in rehabilitation of degraded tropical forests: some lessons from Ghana. - Environment, Development and Sustainability 10(4): 503-518. https://doi.org/10.1007/s10668-006-9077-9. 
[6] Brown, S., Lugo, A. E. (1994): Rehabilitation of tropical lands - a key to sustaining development. - Restoration Ecology 2(2): 97-111.

[7] Budiharta, S., Meijaard, E., Erskine, P. D., Rondinini, C., Pacifici, M., Wilson, K. A. (2014): Restoring degraded tropical forests for carbon and biodiversity. - Environmental Research Letters. https://doi.org/10.1088/1748-9326/9/11/114020.

[8] Cooke, B., Kothari, U. (2001): Participation: The New Tyranny? - Zed Books, London.

[9] Curtis, P. G., Slay, C. M., Harris, N. L., Tyukavina, A., Hansen, M. C. (2018): Classifying drivers of global forest loss. - Science 361(6407): 1108-1111. https://doi.org/10.1126/science.aau3445.

[10] Elliott, S. D., Blakesley, D., Hardwick, K. (2013): Book reviews restoring tropical forests: a practical guide Forest landscape restoration. Integrating natural and social sciences goal-orientated approach to forest landscape restoration restoring tropical forests: a practical guide. - International Forestry Review 15(2): 270-272. http://www.bioone.org/doi/full/10.1505/146554813806948503.

[11] Emerton, L. (1997): Seychelles Biodiversity: Economic Assessment. - Ministry of Foreign Affairs, Planning and Environment, Republic of Seychelles.

[12] Etongo, D. (2021): Analytical study on the relationship between climate change, gender and youth in Seychelles. - UNDP Climate Promise Initiative, Government of Seychelles.

[13] Etongo, D., Fagan, G. H., Kabonesa, C., Asaba, R. B. (2018): Community-managed water supply systems in rural Uganda: the role of participation and capacity development. - Water. DOI: 10.3390/w10091271.

[14] Etongo, D., Monthy, M., Vel, T. (2019): Floristic composition, diversity and its potential for future regeneration between native and exotic species in the Caiman forest of Seychelles. - International Journal of Sustainable Development \& World Ecology. DOI: 10.1080/13504509.2019.1701580.

[15] Etongo, D., Amelie, V., Pouponneau, A., Leal Filho, W. (2020): Identifying and overcoming barriers to climate change adaptation in the Seychelles. - African Handbook of Climate Change Adaptation, Springer Nature Switzerland. https://doi.org/10.1007/9783-030-42091-8_136-1.

[16] Evans, K., Flores, S., Larson, A. M., Marchena, R., Müller, P., Pikitle, A. (2017): Challenges for women's participation in communal forests: experience from Nicaragua's indigenous territories. - Women's Studies International Forum 65: 37-46.

[17] FAO (2005): AQUASTAT Country Profile - Seychelles. - Food and Agriculture Organization of the United Nations (FAO), Rome.

[18] FAO (2014): Forests and gender equality: participatory forestry. http://www.fao.org/3/ai3880e (accessed on 3 January 2021).

[19] Fleischmann, K., Bandara, A., Krütli, P., Massy, S., Mendez, J., Millet, J., Murugaiyan, A., Persaud, I., Schmutz, M., Scholl, M., Vel, T. (2020): Forest Rehabilitation and Assessment of Important Elements of the Ecosystem Services of the Val d'Endor Watershed on the Island of Mahe, Seychelles - Linking Research with Education. - Seychelles Research Journal 2(1): 12-45.

[20] Gann, G. D., McDonald, T., Walder, B., Aronson, J., Nelson, C. R., Jonson, J., Hallett, J. G., Eisenberg, C., Guariguata, M. R., Liu, J., Hua, F., Echeverria, C., Gonzales, E. K., Shaw, N., Decleer, K., Dixon, K. W. (2019): International principles and standards for the practice of ecological restoration. Second edition. - Restoration Ecology 27(S1): S1-S46. https://doi.org/10.1111/rec.13035.

[21] Global Environment Facility. (2020): Taking climate action and fighting fires in the Seychelles - featured story. - https://www.thegef.org/news/taking-climate-action-andfighting-fires-seychelles (accessed on 1 May 2021).

[22] Government of Seychelles (2020): Seychelles' National Climate Change Policy. Ministry of Environment, Energy and Climate Change, Seychelles. http://www.meecc.gov.sc/wp-content/uploads/2019/10/seychelles-national-climatechange-policy-may-2020.pdf (accessed on 1 April 2021). 
[23] Gurung, A., Bista, R., Karki, R., Shrestha, S., Uprety, D., Oh, S. E. (2013): Communitybased forest management and its role in improving forest conditions in Nepal. - Smallscale Forestry (12): 377-388.

[24] Hahn, K., Emborg, J., Madsen, P., Bo Larsen, J. (2004): Forest Rehabilitation in Denmark Using Nature-Based Forestry. - John, A., Palle, M. (eds.) Restoration of Boreal and Temperate Forests. CRC, Boca Raton, pp. 299-317. https://doi.org/10.1201/9780203497784.ch19.

[25] Henriette, E., Nourice, B., Lesperance, M., Laboudallon, V., Lesperance, D. (2013): Comparison of two different replanting tech-niques on degraded soils. Replanting and enhancing community participation of degraded forest lands: a demonstration pro-ject at Pt Chevalier, Praslin, Seychelles. - GOS-UNDP-GEF Small Grant Project.

[26] Kapisen. (2008): Habitat Restoration - Experiences from the field. - Plant Conservation Action Group, Seychelles.

[27] Kueffer, C., Beaver, K., Mougal, J. (2013): Case Study: Management of Novel Ecosystems in the Seychelles. - In: Hobbs, R. J., Higgs, E. S., Hall, C. M. (eds.) Novel Ecosystems: Intervening in the New Ecological World Order. First Ed. John Wiley \& Sons, Ltd, Hoboken, NJ.

[28] Makunga, J. E., Misana, S. B. (2017): The extent and drivers of deforestation and forest degradation in Masito-Ugalla ecosystem, Kigoma Region, Tanzania. - Open Journal of Forestry (7): 285-305.

[29] Marshall, B. K., Jone, R. E. (2005): Citizen participation in natural resource management: Does representativeness matter? - Sociological Spectrum (25): 715-737.

[30] Matsvange, D., Sagonda, R., Kaundikiza, M. (2016): The role of communities in sustainable land and forest management: the case of Nyanga, Zvimba and Guruve districts of Zimbabwe. - Journal of Disaster Risk Studies 8(3): 1-11.

[31] Mbow, C., Fensholt, R., Rasmussen, K., Diop, D. (2013): Can vegetation productivity be derived from greenness in a semi-arid environment? Evidence from ground-based measurements. - Journal of Arid Environment (97): 56-65.

[32] Ministry of Environment, Energy and Climate Change (MEECC) and UNCCD (2018): Final Country Report Land Degradation Neutrality (LDN) Setting Programme. Republic of Seychelles.

[33] OECD (2013): «Seychelles», in OECD/, African Economic Outlook 2013 - Structural Transformation and Natural Resources. - OECD Publishing, Paris. DOI: http://dx.doi.org/10.1787/aeo-2013-41-en.

[34] Ouedraogo, I., Mbow, C., Balinga, M., Neufeldt, H. (2015): Transitions in land use architecture under multiple human driving forces in a semi-arid zone. - Land 4: 560-577.

[35] Raufirad, V., Hunter, R., Khalili, R., Bagheri, S. (2017): Drivers of local people's participation in sustainable natural resource management: a case study in central Iran. Local Environment (22): 880-893.

[36] Senterre, B. (2009): Distribution and Determinants of Forest Fires and Land Degradation on Praslin, Seychelles. - Consultancy Report, Plant Conservation Action Group, Victoria, Mahé, Seychelles.

[37] Senterre, B. (2015): Capacity development for sustainable land management rehabilitation of burned forest areas. - Plant Conservation Action Group, Seychelles.

[38] Senterre, B., Lesperance, M., Bunce, S., Henriette, E., Jean-baptiste, M., Laboudallon, V. (2012): Implementation of post fire rehabilitation trials on the Island of Praslin, Seychelles. - GOS-UNDP-GEF.

[39] Seychelles News Agency (2015): Barren no more - Seychelles NGO reaches out to make Praslin Island green again. http://www.seychellesnewsagency.com/articles/2236/Barren+no+more (accessed on 27 April 2021).

[40] Seychelles News Agency (2020): Reforestation campaign in Seychelles on target to plant 250,000 trees between 2020-2024. 
http://www.seychellesnewsagency.com/articles/14046/Reforestation+campaign+in+Seyc helles (accessed on 27 April 2021).

[41] Stéphenne, N., Lambin, E. F. (2004): Scenarios of land-use change in Sudano-sahelian countries of Africa to better understand driving forces. - GeoJournal (61): 365-379.

[42] Sulieman, H. M. (2018): Exploring divers of forest degradation and fragmentation in Sudan: the case of Erawashda Forest and its surrounding community. - Science of the Total Environment (621): 895-904. https://doi.org/10.1016/j.scitotenv.2017.11.210.

[43] Thompson, I. D., Okabe, K., Tylianakis, J. M., Kumar, P., Brockerhoff, E. G., Schellhorn, N. A., Parrotta, J. A., Nasi, R. (2011): Forest biodiversity and the delivery of Ecosystem goods and services: translating science into Policy. - BioScience 61(12): 972-981.

[44] UNDP (2013): Project Document Government of Seychelles and UNDP Ecosystem Based Adaptation to Climate Change in Seychelles. - Ministry of Agriculture, Climate Change and Environment.

[45] United Nations (1975): Popular Participation in Decision Making for Development. - UN Department for Economics and Social Affairs, New York.

[46] Vásquez-Grandón, A., Donoso, P. J., Gerding, V. (2018): Forest degradation: when is a forest degraded? - Forests 9(11): 1-13. https://doi.org/10.3390/f9110726.

[47] Wekesa, I. W. (2017): Examining the role of community participation in forest management and conservation in Kimothon forest, Transnzoia County, Kenya. - MSc Dissertation, University of Nairobi, Kenya.

[48] Yesuf, G., Brown, K. A., Walford, N. (2019): Assessing regional-scale variability in deforestation and forest degradation rates in a tropical biodiversity hotspot. - Remote Sensing in Ecology and Conservation 5(4): 346-359. https://doi.org/10.1002/rse2.110.

[49] Yin, R., Zulu, L., Qi, J., Freudenberger, M., Sommerville, M. (2016): Empirical linkages between devolved tenure systems and forest conditions: challenges, findings, and recommendations. - Forest Policy and Economics (73): 294-299.

\section{APPENDIX}

Appendix 1. A comprehensive lists of indigenous, endemic and exotic tree species planted bY TRASS on degraded forest areas on Praslin Island

\begin{tabular}{|c|c|c|}
\hline Local name & Scientific name & Status \\
\hline Bwa dir & Pyrostria bibracteata & Indigenous \\
\hline Bwa gayak & Intsia bijuga & Indigenous \\
\hline Bwa kalou & Memecylon elaeagni & Endemic \\
\hline Bwa kwiyer & Tabernaemontana caffeoides & Indigenous \\
\hline Bwa mon per & Pouteria obovata & Indigenous \\
\hline Bwa ponm & Syzygium wrightii & Endemic \\
\hline Bwa rouz & Dillenia feruginea & Endemic \\
\hline Bwa sandel & Draceana reflexa & Indigenous \\
\hline Bwa siro & Premna seratifolia & Indigenous \\
\hline Bwadnat & Mimusops sechellarum & Endemic \\
\hline Kafe maron gran fey & Paragenipa wrightii & Endemic \\
\hline Lafous gran fey & Ficus lutea & Indigenous \\
\hline Lagati & Adenantera pavivona & Indigenous \\
\hline Letiver & Mapanea sp. & Endemic \\
\hline Prin maron & Ludia mauritiana & Endemic \\
\hline Vetiver & Chrysopogon zizanioides & Exotic \\
\hline Bwa bannann & Polyscias crassa & Endemic \\
\hline
\end{tabular}




\begin{tabular}{c|c|c} 
Bwa koulev & Psychotria pervillei & Endemic \\
Bwadrenet & Dodonaea viscosa & Indigenous \\
Kafe maron pti fey & Erythroxylum sechellarum & Endemic \\
Koko maron & Curculigo seychellensi & Endemic \\
Latanyen fey & Phoenicophorium borsigianum & Endemic \\
Latanyen milpat & Nephosperma vanhoutteanum & Endemic \\
Palmis & Deckenia nobilis & Endemic \\
Vakwa parasol & Martiledendron hornei & Endemic \\
Bwa zoliker & Pittosporum senacia subsp. wrightii & Endemic \\
Kapisen & Northea hornei & Endemic \\
Lantannyen lat & Verschaffeltia splendida & Endemic \\
Lantannyen oban & Roscheria melanochaetes & Endemic \\
Lerb razwar & Lophoschoenus hornei & Endemic
\end{tabular}

Appendix 2. Participation of community members at the planning, implementation and monitoring stages of forest rehabilitation on Praslin

\begin{tabular}{|c|c|c|c|c|}
\hline \multirow{2}{*}{ Location } & & \multicolumn{2}{|c|}{ Location of householder } & \multirow{2}{*}{ Total $(N)$} \\
\hline & & Grand Anse & Baie St. Anne & \\
\hline \multirow{6}{*}{ Planning Stage } & Attended meetings & $\begin{array}{c}9 \\
(20.9) \\
\end{array}$ & $\begin{array}{c}10 \\
(23.3) \\
\end{array}$ & 19 \\
\hline & Suggested information & $\begin{array}{c}11 \\
(25.6) \\
\end{array}$ & $\begin{array}{c}10 \\
(23.3) \\
\end{array}$ & 21 \\
\hline & Suggested any idea & $\begin{array}{c}10 \\
(23.3) \\
\end{array}$ & $\begin{array}{c}10 \\
(23.3) \\
\end{array}$ & 20 \\
\hline & Motivated community members & $\begin{array}{c}9 \\
(20.9) \\
\end{array}$ & $\begin{array}{c}14 \\
(32.6) \\
\end{array}$ & 23 \\
\hline & Shared information & $\begin{array}{c}10 \\
(23.3) \\
\end{array}$ & $\begin{array}{c}13 \\
(30.2) \\
\end{array}$ & 23 \\
\hline & Total $(N)$ & 49 & 57 & 106 \\
\hline \multirow{7}{*}{ Implementation } & Raise nursery & $\begin{array}{c}18 \\
(11.7) \\
\end{array}$ & $\begin{array}{c}10 \\
(6.5) \\
\end{array}$ & 28 \\
\hline & Prepare sites to be restored & $\begin{array}{c}14 \\
(9.1) \\
\end{array}$ & $\begin{array}{c}17 \\
(11.0) \\
\end{array}$ & 31 \\
\hline & Select nursery tree species & $\begin{array}{c}14 \\
(9.1) \\
\end{array}$ & $\begin{array}{c}10 \\
(6.5) \\
\end{array}$ & 24 \\
\hline & Transportation of seedlings & $\begin{array}{c}54 \\
(35.1) \\
\end{array}$ & $\begin{array}{c}53 \\
(34.4) \\
\end{array}$ & 107 \\
\hline & Planting of trees & $\begin{array}{c}64 \\
(41.6) \\
\end{array}$ & $\begin{array}{c}53 \\
(34.4) \\
\end{array}$ & 117 \\
\hline & Attended training programs & $\begin{array}{c}56 \\
(36.4)\end{array}$ & $\begin{array}{c}60 \\
(32.5)\end{array}$ & 116 \\
\hline & Total $(N)$ & 220 & 203 & 423 \\
\hline \multirow{6}{*}{ Monitoring } & Participated in site visit & $\begin{array}{c}8 \\
(25.8) \\
\end{array}$ & $\begin{array}{c}5 \\
(16.1) \\
\end{array}$ & 13 \\
\hline & Engaged in enrichment planting & $\begin{array}{c}17 \\
(54.8) \\
\end{array}$ & $\begin{array}{c}5 \\
(16.1) \\
\end{array}$ & 22 \\
\hline & Motivate other community members & $\begin{array}{c}10 \\
(32.3) \\
\end{array}$ & $\begin{array}{c}6 \\
(19.4) \\
\end{array}$ & 16 \\
\hline & Maintain fire breaks & $\begin{array}{c}7 \\
(22.6) \\
\end{array}$ & $\begin{array}{c}2 \\
(6.5) \\
\end{array}$ & 9 \\
\hline & Collect data for TRASS & $\begin{array}{c}6 \\
(19.4) \\
\end{array}$ & $\begin{array}{c}3 \\
(9.7) \\
\end{array}$ & 9 \\
\hline & Total $(N)$ & 48 & 21 & 69 \\
\hline
\end{tabular}


Appendix 3. Questionnaire

Assessing local communities' involvement in the rehabilitation of degraded forests: some lessons from Praslin Island

I am a final year student at the University of Seychelles currently doing my $3^{\text {rd }}$ year thesis in Environmental science within the framework of the Ecosystem Based Adaptation to Climate Change Project Seychelles. My research aims to assess community involvement in forest rehabilitation on Praslin. The feedback provided from participants will shed light on the factors that influence community involvement and thus encourage relevant stakeholders including experts and scientists to better engage with communities. The findings of this study can also help decision makers to better plan and allocate funding for rehabilitation activities and adapt this strategy in other areas. Your participation is very important to the success of my thesis and the information provided will be treated with all confidentiality.

\section{$\underline{\text { Section A - Socio demographic information }}$}

1. Gender: $\square$ male, $\square$ female 2. Age $\ldots . . . . . .$.

3. Family size (in numbers)

4. How many household members are between the ages 16 and 60 years of age?...........

5. Of the household members that are between the ages of $16-60$ years (Q. 4 above), how many of them are employed?

6. Gender of the household head. $\square$ male, $\square$ female

7. Address:

\section{$\underline{\text { Section B -Socioeconomic information }}$}

8. Highest level of education

$\square$ Primary

$\square$ Secondary

$\square$ Post-Secondary

$\square$ University degree/higher
8. Occupation

$\square$ Farmer

$\square$ Fishermen

$\square$ Business owner

$\square$ Civil servant

$\square$ Others

9. Do you directly financially benefit from rehabilitation?

$\square$ yes , $\square$ no , $\square$ I don't know 


\section{$\underline{\text { Section C }}$}

10. Are you a member of any community organization on Praslin?

$\square$ yes, $\square$ no, $\square$ I don’t know

11. What do you think could be the main cause of forest fire on Praslin?

12. Do you think tree planting benefit fire ravaged sites through ...

\begin{tabular}{|cll|l|l|}
\cline { 4 - 5 } \multicolumn{1}{l|}{} & Yes & No & $\begin{array}{l}\text { I don't } \\
\text { know }\end{array}$ \\
\hline i) & Soil protection from erosion & & & \\
\hline ii) & Protection of biodiversity & & & \\
\hline iii) & Improving the landscape & & & \\
\hline iv) & Improving water quality and quantity & & & \\
\hline v) & $\begin{array}{l}\text { Carbon capture for climate change } \\
\text { mitigation }\end{array}$ & & & \\
\hline vi) & Other: & & & \\
\hline
\end{tabular}

13. Do you think ... is a problem for tree planting on fire ravaged sites?

\begin{tabular}{|cll|l|l|}
\cline { 4 - 5 } \multicolumn{1}{l|}{} & Yes & No & $\begin{array}{l}\text { I don't } \\
\text { know }\end{array}$ \\
\hline i) & Shortage of seedlings & & & \\
\hline ii) & Recurrent fire & & & \\
\hline iii) & High tree mortality rate & & & \\
\hline iv) & Inadequate knowledge/skills on restoration & & & \\
\hline v) & Ownership of planted trees & & & \\
\hline vi) & Other: & & & \\
\hline
\end{tabular}

14. Have you ever participated in Rehabilitation work on Praslin?

$\square$ yes, $\square$ no

15. (a) If, yes to the question above, with which of the following organizations?

$\square$ SNPA , $\square$ MEECC , $\square$ TRASS , $\square$ Others 
16. (b) Frequency of participation?

$\square$ Once, $\square$ Several times per week, $\square$ Several times per month, $\square$ Several times per year

(But if no to the question above, please move to Section $E$. Those who answer yes, should end in Section D)

\section{$\underline{\text { Section D-Participation indicators at different stages of forest rehabilitation }}$}

\section{Planning stage}

17. Did you participate in any of the following activities?

\begin{tabular}{|l|l|l|l|}
\cline { 2 - 4 } \multicolumn{1}{l|}{} & Yes & No & $\begin{array}{l}\text { I don't } \\
\text { know }\end{array}$ \\
\hline Attended planning meetings for forest restoration? & & & \\
\hline $\begin{array}{l}\text { Suggested information on how the fire ravaged forest } \\
\text { should be restored }\end{array}$ & & & \\
\hline $\begin{array}{l}\text { Suggested any idea during planning regarding techniques in } \\
\text { the restoration of the fire damaged sites such as track } \\
\text { cutting, weeding, preferred tree species to be planted, etc. }\end{array}$ & & & \\
\hline $\begin{array}{l}\text { Motivate your fellow community members to participate in } \\
\text { planning regarding forest restoration on Praslin? }\end{array}$ & & & \\
\hline $\begin{array}{l}\text { Share information or experience about forest restoration } \\
\text { after participating in planning meetings? }\end{array}$ & & & \\
\hline
\end{tabular}

$\underline{\text { Implementation stage }}$

18. Did you participate in any of the following activities?

\begin{tabular}{|c|c|c|c|}
\hline & Yes & No & $\begin{array}{l}\text { I don't } \\
\text { know }\end{array}$ \\
\hline \multicolumn{4}{|l|}{$\begin{array}{l}\text { Raising the TRASS nursery either through financial } \\
\text { contribution or labour }\end{array}$} \\
\hline \multicolumn{4}{|l|}{$\begin{array}{l}\text { Preparing the restored sites in activities such as track } \\
\text { cutting, slashing, fire breaks, etc. }\end{array}$} \\
\hline \multicolumn{4}{|l|}{ Selecting the tree species raised in the nursery } \\
\hline \multicolumn{4}{|l|}{$\begin{array}{l}\text { Transportation of seedlings from the nursery to the sites to } \\
\text { be restore }\end{array}$} \\
\hline \multicolumn{4}{|l|}{ Tree planting at the fire damaged sites } \\
\hline $\begin{array}{l}\text { Training program on restoration on issues such as how to } \\
\text { raise a nursery, types of trees to be planted, how to restore } \\
\text { degraded sites, etc. }\end{array}$ & & & \\
\hline
\end{tabular}




\section{Monitoring stage}

19. Do you participate in any of the following activities?

\begin{tabular}{|l|l|l|l|}
\cline { 2 - 4 } \multicolumn{1}{l|}{} & Yes & No & $\begin{array}{l}\text { I don't } \\
\text { know }\end{array}$ \\
\hline Site visit after trees are planted in the degraded site & & & \\
\hline Replanting of trees that could not survive & & & \\
\hline $\begin{array}{l}\text { Motivate fellow community member to contribute labour or } \\
\text { money for replanting, weeding, track cutting, etc. }\end{array}$ & & & \\
\hline Maintaining fire breaks & & & \\
\hline Providing/collecting data for TRASS database & & & \\
\hline
\end{tabular}

\section{$\underline{\text { Section E (Non-Participants) }}$}

20. Do you know of the NGO TRASS? $\square$ yes , $\square$ no , $\square$ I don’t know

21. Do you know of the work that they do? $\square$ yes , $\square$ no , $\square$ I don't know

22. Do you think the work they are doing is important? $\square$ yes , $\square$ no , $\square$ I don't know

23. How?

24. Do you wish to participate in rehabilitation works undertaken by TRASS?

$\square$ yes , $\square$ no , $\square$ I don't know

25. If yes to the above question, what is currently preventing you from participating?

$\square$ Time constraint

$\square$ Access to site/too far and steep

$\square$ Lack of information on activities

$\square$ Health issues

$\square$ Others (please specify)

26. There are different activities involve in the rehabilitation works undertaken by TRASS. Are any of the following activities of interest to you?

$\square$ Nursery Maintenance

$\square$ Track cutting

$\square$ Tree planting

$\square$ Site monitoring 
27. Which of the stages of forest restoration will you like to be involved in?

(Multiple choice question)

$\square$ Planning stage

$\square$ Implementation stage

$\square$ Monitoring stage

28. What do you think could be done to improve on the restoration of the fire ravaged forests on Praslin?

29. Would you like to be contacted for future activities? $\square$ yes ， $\square$ no ， $\square$ I don’t know

Contact details:

Estimated distance from home to rehabilitated forest $(\mathrm{km})$ 